\title{
Reviews and syntheses: Australian vegetation phenology: new insights from satellite remote sensing and digital repeat photography
}

Caitlin E. Moore ${ }^{1,2}$, Tim Brown ${ }^{3}$, Trevor F. Keenan ${ }^{4,5}$, Remko A. Duursma $^{6}$, Albert I. J. M. van Dijk ${ }^{7}$ Jason Beringer ${ }^{8}$, Darius Culvenor ${ }^{9}$, Bradley Evans ${ }^{10,11}$, Alfredo Huete ${ }^{12}$, Lindsay B. Hutley ${ }^{13}$, Stefan Maier ${ }^{14}$, Natalia Restrepo-Coupe ${ }^{12}$, Oliver Sonnentag ${ }^{15}$, Alison Specht ${ }^{16,17}$, Jeffrey R. Taylor ${ }^{18}$, Eva van Gorsel ${ }^{19}$, and Michael J. Liddell ${ }^{20}$

${ }^{1}$ School of Earth, Atmosphere and Environment, Monash University, Clayton, VIC 3800, Australia

${ }^{2}$ Genomic Ecology of Global Change, Carl R. Woese Institute for Genomic Biology, University of Illinois, Urbana, IL 61801, USA

${ }^{3}$ Research School of Biology, Plant Sciences, Australian National University, Acton, ACT 0200 Australia

${ }^{4}$ Department of Biological Sciences, Macquarie University, North Ryde NSW 2109, Australia

${ }^{5}$ Lawrence Berkeley National Lab., 1 Cyclotron Road, Berkeley, CA 94720, USA

${ }^{6}$ Hawkesbury Institute for the Environment, University of Western Sydney, Locked Bag 1797, Penrith, NSW 2751, Australia

${ }^{7}$ Fenner School of Environment \& Society, The Australian National University, Acton, ACT 2601, Australia

${ }^{8}$ School of Earth and Environment, University of Western Australia, Crawley 6009, WA, Understory Australia

${ }^{9}$ Environmental Sensing Systems, 16 Mawby Road, Bentleigh East, VIC 3165, Australia

${ }^{10}$ Department of Environmental Sciences, The University of Sydney, Eveleigh, NSW, Australia

${ }^{11}$ Terrestrial Ecosystem Research Network Ecosystem Modelling and Scaling Infrastructure, The University of Sydney, Eveleigh, NSW, Australia

${ }^{12}$ Plant Functional Biology and Climate Change Cluster, University of Technology Sydney, Broadway, NSW, Australia

${ }^{13}$ School of Environment, Research Institute for the Environment and Livelihoods, Charles Darwin University,

Casuarina, NT 0909, Australia

${ }^{14}$ Maitec, P.O. Box U19, Charles Darwin University, Darwin, NT 0815, Australia

${ }^{15}$ Département de Géographie, Université de Montréal, Montréal, QC H3C 3J7, Canada

${ }^{16}$ Geography, Planning and Environmental Management, The University of Queensland, St. Lucia, QLD 4072, Australia

${ }^{17}$ Centre of Analysis and Synthesis of Biodiversity, Domaine de Petit Arbois, Immeuble Henri Poincaré,

Rue Louis Philibert, Aix-en-Provence, France

${ }^{18}$ Institute of Technology Campus, Nova Scotia College System, Halifax, NS B3K 2T3, Canada

${ }^{19}$ CSIRO, Ocean and Atmosphere Flagship, Yarralumla, ACT 2601, Australia

${ }^{20}$ College of Science, Technology and Engineering, James Cook University, Cairns, QLD 4878, Australia

Correspondence to: Caitlin E. Moore (caitlin@ moorescience.com.au)

Received: 4 May 2016 - Published in Biogeosciences Discuss.: 10 May 2016

Revised: 5 August 2016 - Accepted: 22 August 2016 - Published: 13 September 2016 
Abstract. Phenology is the study of periodic biological occurrences and can provide important insights into the influence of climatic variability and change on ecosystems. Understanding Australia's vegetation phenology is a challenge due to its diverse range of ecosystems, from savannas and tropical rainforests to temperate eucalypt woodlands, semiarid scrublands, and alpine grasslands. These ecosystems exhibit marked differences in seasonal patterns of canopy development and plant life-cycle events, much of which deviates from the predictable seasonal phenological pulse of temperate deciduous and boreal biomes. Many Australian ecosystems are subject to irregular events (i.e. drought, flooding, cyclones, and fire) that can alter ecosystem composition, structure, and functioning just as much as seasonal change. We show how satellite remote sensing and ground-based digital repeat photography (i.e. phenocams) can be used to improve understanding of phenology in Australian ecosystems. First, we examine temporal variation in phenology on the continental scale using the enhanced vegetation index (EVI), calculated from MODerate resolution Imaging Spectroradiometer (MODIS) data. Spatial gradients are revealed, ranging from regions with pronounced seasonality in canopy development (i.e. tropical savannas) to regions where seasonal variation is minimal (i.e. tropical rainforests) or high but irregular (i.e. arid ecosystems). Next, we use time series colour information extracted from phenocam imagery to illustrate a range of phenological signals in four contrasting Australian ecosystems. These include greening and senescing events in tropical savannas and temperate eucalypt understorey, as well as strong seasonal dynamics of individual trees in a seemingly static evergreen rainforest. We also demonstrate how phenology links with ecosystem gross primary productivity (from eddy covariance) and discuss why these processes are linked in some ecosystems but not others. We conclude that phenocams have the potential to greatly improve the current understanding of Australian ecosystems. To facilitate the sharing of this information, we have formed the Australian Phenocam Network (http://phenocam.org.au/).

\section{Introduction}

Phenology is the study of the timing of periodic biological occurrences, from flowering and leaf emergence to animal migrations and breeding patterns, all of which vary between and within species and are influenced to a certain degree by the climate (Lieth, 1974; Richardson et al., 2013a). Phenological monitoring allows us to quantify and track seasonal cycles and irregular natural events, as well as how vegetation phenology responds to meteorological events and climate change. At the ecosystem level, the timing of leaf emergence and senescence in plants has a major influence on the length of the growing season (Dragoni et al., 2011; Keenan et al., 2014b). On larger scales, phenological responses feed back to the climate system by altering the land surface energy balance and the coupled cycles of water, carbon, and nutrients from an ecosystem (Peñuelas et al., 2009; Richardson et al., 2013a). Research suggests that contemporary warming has advanced spring onset in the Northern Hemisphere by ca. 2.8 days per decade since the 1970s (Parmesan, 2007), with even higher rates of change (4.8 days per decade) in more recent decades (Keenan et al., 2014b). Likewise, in the Southern Hemisphere, advancement in spring onset has been estimated at a rate of 2.2 days per decade (Chambers et al., 2013).

In response to increasing evidence of earlier spring onsets, the Intergovernmental Panel on Climate Change (IPCC) has placed a high importance on the gathering and interpretation of phenology observations to improve our understanding of the ecological impacts of climate change (Ciais et al., 2013). Understanding the processes that lead to modifications in phenology, as well as the complex links between phenological shifts and climatic variability and change on local, regional, and global scales, requires more detailed field-based observations that underpin larger-scale remote sensing and ecological modelling tools (de Jong et al., 2012; Migliavacca et al., 2012; Melaas et al., 2013).

Repeat photography with digital cameras (phenocams) has emerged as a powerful observational tool for ecological research and evaluation of remote sensing data products and model simulations (Richardson et al., 2007; Migliavacca et al., 2011; Hufkens et al., 2012; Wingate et al., 2015; Brown et al., 2016). Digital images collected from phenocams typically provide red-green-blue (RGB) colour channel information that can be partitioned and converted to quantitative indices (Woebbecke et al., 1995; Gillespie et al., 1987; Sonnentag et al., 2012). These indices have been shown to closely track vegetation colour changes, such as canopy greenness, and are indicative of different plant development stages in a variety of ecosystems (Sonnentag et al., 2011; Inoue et al., 2014; Keenan et al., 2014a; Peichl et al., 2014; Toomey et al., 2015). A loosely organised global phenocam network is emerging with regional networks including the PhenoCam Network (Richardson et al., 2009a) and the National Ecological Observatory Network (NEON) in the USA (Keller et al., 2008), the EUROPhen network in Europe (Wingate et al., 2015; Brown et al., 2016), the Phenological Eyes Network (PEN) in Japan (Nasahara and Nagai, 2015), and most recently, the Australian Phenocam Network (Brown et al., 2016). These networks provide support for phenocam data collection and sharing in the wider scientific community and are a platform for the development of open data and data sharing standards.

Phenology information can also be derived from satellite remote sensing imagery. Satellite data provides spatially explicit time series of vegetation phenology proxies such as the enhanced vegetation index (EVI; Huete et al., 2002) and the normalised difference vegetation index (NDVI; Tucker, 1979), as well as estimates of canopy cover fraction, the 
fraction of absorbed photosynthetically active radiation and leaf area index (LAI) derived from optical remote sensing (Gonsamo and Chen, 2014). In addition, vegetation optical depth and biomass can be derived from radar or passive microwave remote sensing (Andela et al., 2013; Liu et al., 2007, 2011, 2013). Such remotely sensed vegetation phenology proxies can be analysed to estimate temporal changes in the vegetation characteristics on the landscape scale and contribute toward the development of satellite phenology products, such as the MODerate resolution Imaging Spectroradiometer (MODIS) Land Cover Dynamics product (Ganguly et al., 2010) and the Australian satellite land surface phenology product (Broich et al., 2015).

Satellite-derived phenology can be compared to changes observed on smaller scales with phenocams. For example, Hufkens et al. (2012) and Klosterman et al. (2014) used phenocams to evaluate the MODIS MCD12Q2 product for deciduous forests in the north-eastern USA. Despite discrepancies related to spatial scale and site representativeness, the results showed good agreement between the phenocam- and satellite-derived timing of phenological events (i.e. phenophases). For various temperate and boreal forest, grassland, and peatland ecosystems, time series data of canopy greenness derived from phenocam imagery have been used to analyse seasonal changes in net ecosystem exchange (NEE) and gross primary productivity (GPP) (Ahrends et al., 2009; Richardson et al., 2007, 2009b; Zhu et al., 2013; Toomey et al., 2015). Characterising changes in plant physiology (Keenan et al., 2014a), modelling of canopy development (Wingate et al., 2015), and quantifying interannual variation in phenology (Inoue et al., 2014) have also been achieved using phenocams. Despite the promising applications of phenocam data in North America, Europe, and Asia, there has been a slow uptake of phenocam research in Australia, a continent characterized by diverse ecosystem types often with distinctly different phenological characteristics compared to temperate and boreal deciduous ecosystems (Chambers et al., 2013).

The diversity of Australian ecosystems, and their marked differences to Northern Hemisphere temperate deciduous and boreal biomes, poses the challenge of how to best define and quantify vegetation phenology signals, especially due to their responses to irregular natural events such as rainfall, flooding, fire, and extreme temperatures. While the traditional definition of the term phenology as the "timing of recurrent biological events" (Lieth, 1974) is generally assumed to apply to seasonally cyclical events, such as canopy bud burst and senescence in winter-deciduous forests, a closer look at life patterns in many Australian biomes yields a more complex picture of non-seasonal, yet still periodic, events as the major drivers of phenology (Specht and Brouwer, 1975; Pook et al., 1997; Ma et al., 2015).

In this synthesis, we examine the drivers of plant phenological cycles across Australia, illustrate the potential measurement tools available, and suggest future avenues of re- quired research. On the national scale, we demonstrate how satellite observations can be used to characterise broad-scale phenological variability across the continent and discuss the major drivers underlying these patterns. On the ecosystem scale, we highlight the value of using digital image archives obtained from phenocams installed at a selection of contrasting OzFlux sites (Australian and New Zealand flux tower network; see Beringer et al., 2016), for examining the phenology of canopies and individual plants in Australian ecosystems. We discuss how greenness information obtained from phenocam imagery can be compared with flux tower estimates of GPP and why such relationships are stronger from some Australian ecosystems than for others. Finally, we assess the feasibility and effectiveness of phenocams for continuously observing Australia's diverse ecosystems.

\section{Drivers of phenology in Australia}

Australian ecosystems include a diverse range of biomes spanning tropical savannas and rainforests in the north to arid and semi-arid shrublands and grasslands in the centre and finishing with temperate evergreen forests and woodlands in the south (Fig. 1; see also Beringer et al., 2016, in this issue). Stern and Dehani (2013) recently identified the major climate zones in Australia as ranging from equatorial and tropical in the north through to subtropical, desert, grassland, and temperate in the south (Fig. 1). This wide-ranging climatic variability results in long-term mean annual rainfall ranging from 134 to $2804 \mathrm{~mm}$ and mean annual air temperature ranging from 3.8 to $29.0^{\circ} \mathrm{C}$ (from $1961-1990$ data gridded at $0.1^{\circ}$ (Australian Bureau of Meteorology, 2013; Fig. 1)). Therefore, Australian vegetation has adapted a number of unique phenologies to respond to these climatic drivers.

Temperature is an important phenological driver in Australian ecosystems (Chambers et al., 2013), just as it is in temperate deciduous and boreal ecosystems in the Northern Hemisphere. However, Australian ecosystem dynamics are arguably influenced more strongly by the availability of water, because $70 \%$ of its land mass is classified as arid or semi-arid deserts and grasslands (Fig. 1, Chambers et al., 2013). The response of LAI and vegetation cover to rainfall events, mean annual rainfall, and the corresponding soil water availability is well documented (Pook, 1985; Specht and Specht, 1989; Ellis and Hatton, 2008; Donohue et al., 2009, 2013; Andela et al., 2013; Duursma et al., 2016). Similarly, vegetation density closely follows climate gradients in average rainfall (Ellis and Hatton, 2008; Donohue et al., 2009; Hutley et al., 2011; Ma et al., 2013). Large-scale variability in climatic conditions governs vegetation distribution across the continent and most Australian vegetation has adapted in some form around the need to maintain a balance between water access and water loss.

Among the exceptions to this concept are temperate and tropical rainforest ecosystems found along the east coast of 

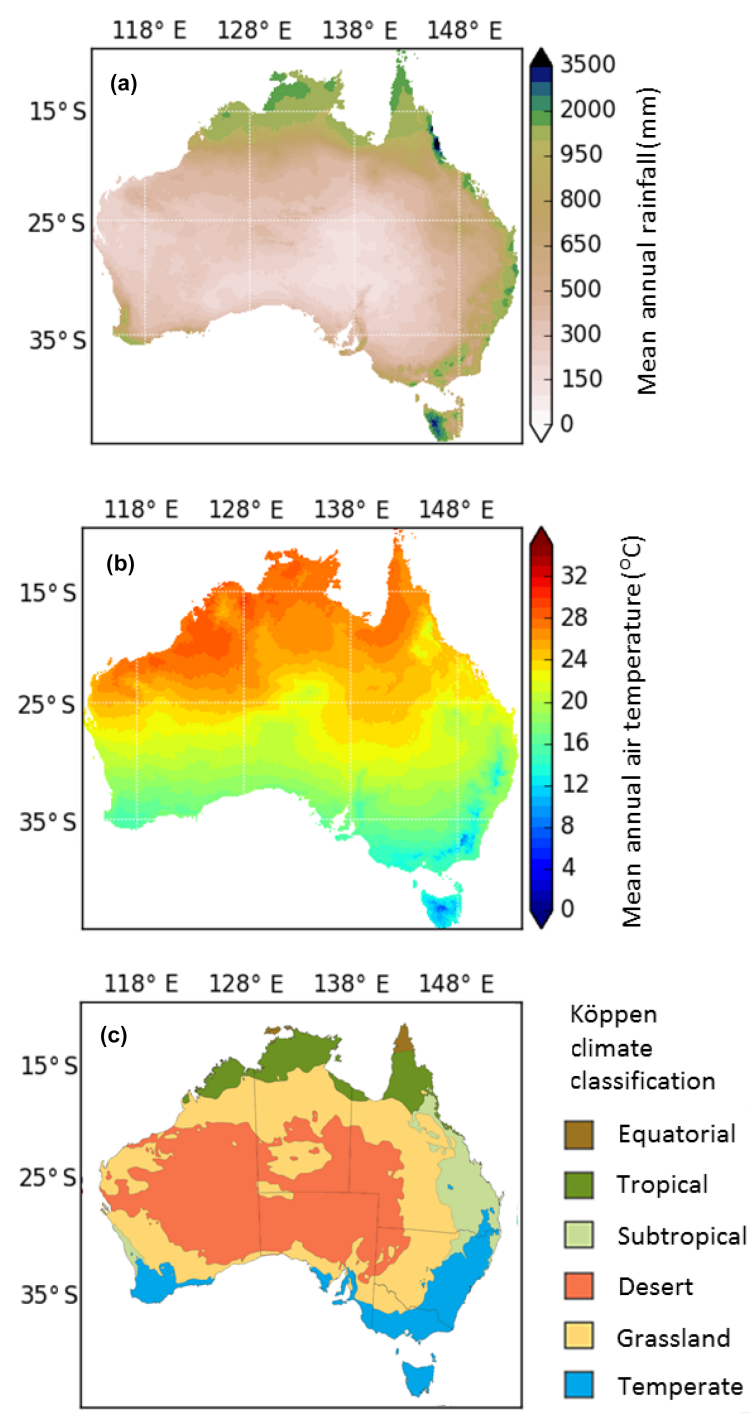

Figure 1. Mean annual rainfall (a), mean annual air temperature (b) and the major zone Köppen-Geiger climate classification (c) for Australia from 1961 to 1990 (data source: Australian Bureau of Meteorology, 2013).

the continent, where rainfall is almost continually in excess of water requirement (Fig. 1). In contrast, $C_{4}$ grass phenology is driven by wet-season rainfall across Australia's tropical savanna ecosystems, whilst the $C_{3}$ eucalypt overstorey remains relatively static throughout the year, supported by access to deeper soil water reserves (Walker and Langridge, 1997; Eamus et al., 2002; Hutley et al., 2011). Recurrent dry spells and droughts are often associated with high-mortality events in south-western Australia (Evans and Lyons, 2013; Matusick et al., 2013) and in both riparian (Davies et al., 2008; Gehrke et al., 2006) and non-riparian trees (Semple et al., 2010) in south-eastern Australia. Over longer timescales, non-seasonal shifts in temperature and rainfall, as well as second-order effects on soil water availability, have been at- tributed to forest declines (Evans et al., 2013) and mortality (Evans and Lyons, 2013) that can be linked to changes in phenology.

Fire events commonly occur in Australia and are often triggered by drought and dry conditions, which are not traditionally regarded as phenological drivers but nonetheless have a cyclical character in many Australian ecosystems (Maier and Russell-Smith, 2012). Most eucalypt forests in Australia suffer periodic burning and have adapted strategies to allow prompt regrowth after fire (epicormic growth) to obtain a rapid photosynthetic advantage over other vegetation competing for light (Hodgkinson, 1998; Burrows, 2008). Drought can also trigger insect attacks, which have been observed to result in rapid canopy defoliation and ecosystem carbon loss in a eucalypt forest in south-eastern Australia (Keith et al., 2012; van Gorsel et al., 2013). Seasonal grazing due to insects and other arboreal browsers is another periodic disturbance in Australian ecosystems that can inhibit new leaf production and greatly modify the canopy, thus thwarting phenology responses observable in these ecosystems (Lowman, 1985; Specht, 1985; Melzer et al., 2000).

Temporal variations in leaf colour, although not as pronounced as in temperate deciduous forests, do occur in evergreen species that dominate Australian ecosystems. For example, eucalypt leaves can contain large amounts of anthocyanin, causing a reddening of the leaf surface (Sharma and Crowden, 1974). While there is no general consensus on why anthocyanins are present in leaves (Gould et al., 2000), their accumulation is associated with the expansion and subsequent predation of young foliage (Close and Beadle, 2003), nutrient deficits that affect photosynthesis (Terashima and Evans, 1988; Sugiharto et al., 1990), or as a protection against solar radiation (Gould, 2004). The accumulation of foliar anthocyanin has been observed in leaves of many Australian plant species (Nittler and Kenny, 1976; Hodges and Nozzolillo, 1996; Kumar and Sharma, 1999; Close et al., $2000,2001 \mathrm{a}, \mathrm{b})$, as has reddening of adult leaves due to a changing anthocyanin-to-chlorophyll ratio when exposed to stressors such as cold or drought (Close et al., 2001a; Stone et al., 2001; Barry et al., 2009). In other cases, exposure to stressful processes can result in a decrease in leaf chlorophyll content, accompanied by or as the precursor to, visible chlorosis (Coops et al., 2004). Such leaf reddening events are visible and often occur in a cyclical manner; therefore, they can be considered as phenological in nature and may be identified by phenocams. The examples listed in this section illustrate the wide ranging drivers of vegetation phenology in Australian ecosystems and highlight the need for continued research to better understand how phenology may respond to climate change in the future. 

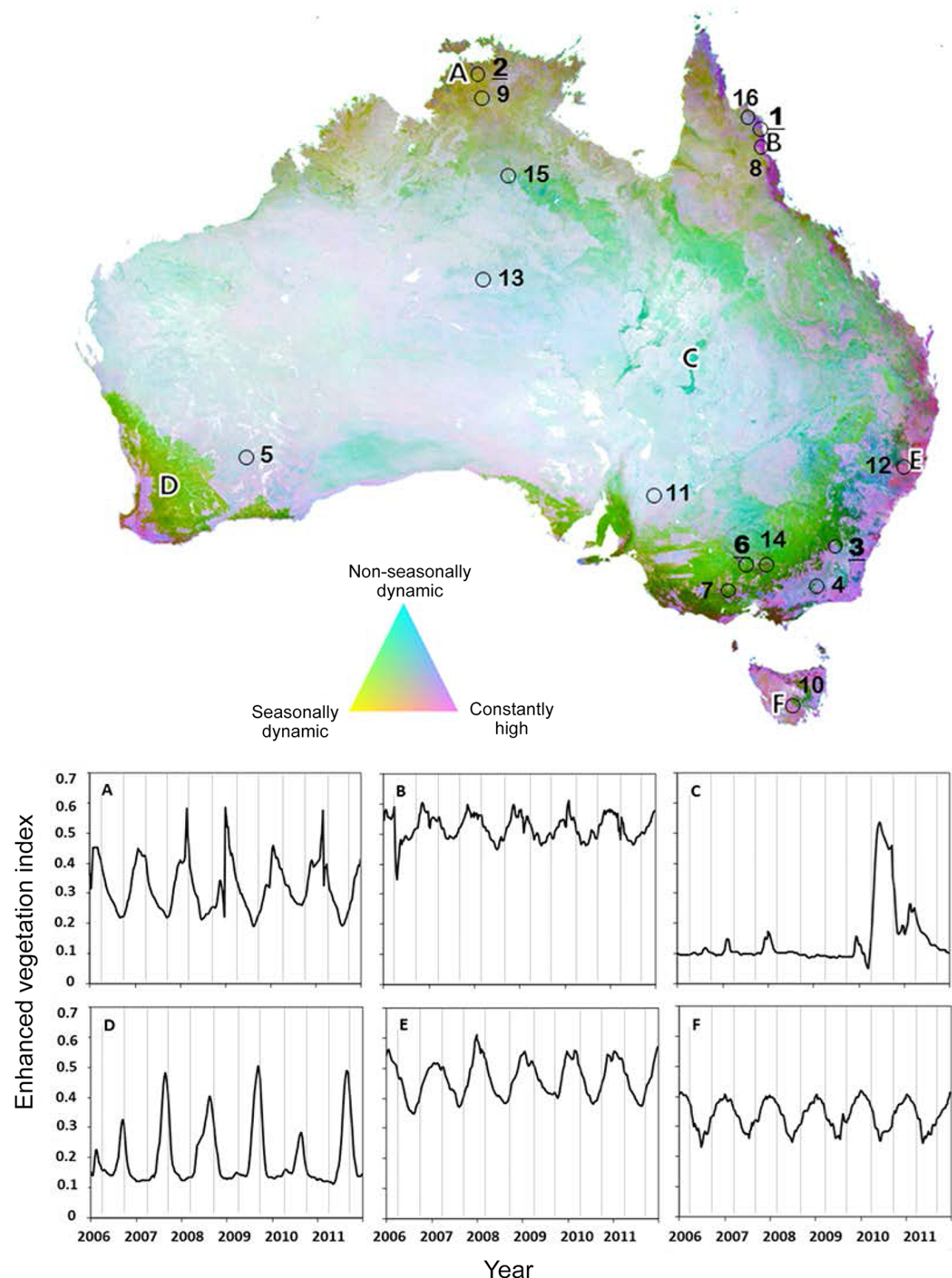

Figure 2. Enhanced vegetation index (EVI) map of Australia obtained from MODIS global $0.05^{\circ}$ 8-day reflectance composites for 20002012 (MOD09) with a selection of six pixels to demonstrate the following. Yellow areas have a strong seasonal cycle, such as Howard Springs at point A. Cyan areas have relatively strong but non-seasonal variations in EVI, such as Channel Country at point C. Magenta areas have a more constant moderate to high EVI with less temporal variability compared with other sites, which include sites such as Cape Tribulation at point B, the central coast at point E and the Tasmanian highlands at point F. Green areas have both seasonal and non-seasonal variation, such as the wheat belt of Western Australia at point D. Blue areas have relatively high greenness but strong non-seasonal variation. The paler colours of the map centre show weaker EVI signals. The SD in seasonally adjusted anomalies (yellow) was scaled from 0 to 0.1 ; $\mathrm{SD}$ in mean seasonal cycle (cyan) from 0 to 0.1 ; and mean EVI (magenta) from 0 to 0.6. Also included are the locations (and Fluxnet codes where applicable) of currently operating phenocams in Australia. Numbers refer to 1. Cow Bay (AU-Cow); 2. Howard Springs (AU-How); 3. Tumbarumba (AU-Tum); 4. Karawatha; 5. Great Western Woodlands (AU-GWW); 6. Whroo (AU-Whr); 7. Wombat (AU-Wom); 8. Robson Creek (AU-Rob); 9. Litchfield (AU-Lit); 10. Warra (AU-Wrr); 11. Calperum (AU-Cpr); 12. Cumberland Plain (AU-Cum) and EucFACE; 13. Alice Springs (AU-ASM); 14. Riggs Creek (AU-Rig); 15. Sturt Plains (AU-Stp); 16. Cape Tribulation (AU-Ctr). Phenocam data used in this paper are from sites 1, 2, 3, and 6 . 


\section{Continental-scale phenology from satellite sensors}

To characterise the phenological diversity of Australian ecosystems on the continental scale, we used satellite remote sensing observations to map land surface seasonal variability in measures of vegetation greenness. For this, we used EVI as a phenology indicator to construct an EVI seasonality map for Australia using 8-day composites of spectral reflectance observations from MODIS (MCD43C 4.005 product) at $0.05^{\circ}$ (ca. $5 \mathrm{~km}$ ) resolution for the period 2000-2012. We calculated EVI (Huete et al., 2002) as Eq. (1):

$\mathrm{EVI}=G \frac{\rho_{\mathrm{NIR}}-\rho_{\text {red }}}{\rho_{\mathrm{NIR}}+L+C_{1} \times \rho_{\text {red }}-C_{2} \times \rho_{\text {blue }}}$,

where $\rho_{\text {NIR }}, \rho_{\text {red }}$, and $\rho_{\text {blue }}$ are atmospherically corrected spectral reflectance in near-infrared, red, and blue wavelength ranges, respectively; $G$ is a gain factor $(G=2.5)$; $C_{1}$ and $C_{2}$ are aerosol resistance coefficients $\left(C_{1}=6, C_{2}=\right.$ 7.5); and $L$ is a soil-adjustment factor $(L=1)$. Values of EVI below 0 and above 1 were removed, as these pixels were either contaminated by cloud or open water.

The mean seasonal pattern for each pixel, based on variability in EVI from 2000-2012, was calculated as the mean annual pattern in 8-day values over the 13 years. Subsequently, this seasonal pattern was subtracted from the time series for each pixel to yield seasonally adjusted anomalies. We then calculated (i) the standard deviation in these seasonally adjusted anomalies $(n=585)$, as well as (ii) the overall mean EVI and (iii) the standard deviation of the mean seasonal pattern $(n=45)$. Combining these three measures allowed us to distinguish areas in Australia where the phenological signal was primarily "non-seasonally dynamic" (EVI varied but not in accordance with seasons), "constantly high" (EVI remained high year-round), or "seasonally dynamic" (EVI showed regular seasonal variability).

To explore phenological variability in more detail around Australia, EVI is displayed by time series plots for selected sites (Fig. 2a-f). Our continental phenological response map shows that the tropical region of northern Australia (Fig. 2a, b) experiences a predictable seasonal phenology, as it receives reliable summer monsoon rainfall (Cook and Heerdegen, 2001). In contrast, large areas of Australia are characterised by non-seasonal variability in vegetation cover (Fig. 2c). These areas primarily fall within the arid interior, as well as in the south-western and south-eastern subhumid regions, where rainfall variability was particularly strong during the observation period, including the worst multi-year drought on record (Van Dijk et al., 2013; Broich et al., 2014).

Tropical savanna ecosystems in northern Australia depict both seasonal (monsoon-driven) and non-seasonal changes (fire-driven), represented by EVI for Howard Springs (location A), which has a high level of variability as shown by the highest amplitude in EVI for all sites (i.e. amplitude of 0.31; Fig. 2a). In contrast, the tropical rainforest at Cape Tribulation (location B) shows a regular but low level of seasonal variability, where the amplitude varies much less than that for site A (i.e. amplitude of 0.15; Fig. 2b). An exception to this regular cycle is the impact of cyclone Larry in early 2006. Cape Tribulation is located nearby and within the same tropical rainforest as the Cow Bay OzFlux site (Fig. 2b). Both sites show the same seasonal trend, and these changes in EVI can be related to changes in NEE that are observed at the OzFlux towers at both sites (Beringer et al., 2016).

Further inland, floodplain vegetation in the arid Channel Country (location C) responds primarily to infrequent and irregular flood events produced in the large upstream catchment. For a flood event in 2010, the time series shows an initial reduction in EVI (open water produces negative EVI; Huete et al., 2002) with a subsequent green flush (i.e. amplitude increases from 0.1 to 0.48; Fig. 2c). The Western Australian wheat belt (location D) shows a winter peak in vegetation (i.e. June-September in the Southern Hemisphere), corresponding with maximum leaf area before the cropping of winter wheat (i.e. EVI amplitude of 0.41 ; Fig. 2 d). In contrast to location $\mathrm{C}$, the year 2010 was the driest on record with poor harvests, recognisable as a lower EVI signal for that year at location D. Subtropical evergreen forests on the central New South Wales (NSW) coast (location E) show a seasonal cycle (i.e. amplitude of 0.20; Fig. 2e) more like that of tropical rainforests further north (location B), which is most likely a phenological adaptation to rainfall during both summer and winter (Bowman, 2000). Highland vegetation in Tasmania (location F) shows a summer green phenology that is more reminiscent of temperate forest ecosystems in the Northern Hemisphere. These selected examples suggest that for most, but not all, of Australia's ecosystems, it is not temperature or radiation but water availability and extreme events that drive vegetation phenology. Furthermore, in addition to the more or less predictable seasonal variations in precipitation, there is very strong variability in rainfall between years due to the strong influence of ocean circulation modes such as the El Niño-Southern Oscillation, Indian Ocean Dipole, Southern Annular Mode, and Pacific Decadal Oscillation (Van Dijk et al., 2013; Broich et al., 2014; Cleverly et al., 2016).

\section{Ecosystem-scale phenology from phenocams}

Digital repeat photography has already been shown to provide high temporal-resolution phenology information throughout many vegetation biomes in the Northern Hemisphere (i.e. Richardson et al., 2007; Migliavacca et al., 2011; Sonnentag et al., 2012; Keenan et al., 2014a; Klosterman et al., 2014; Toomey et al., 2015). Images collected by phenocams are typically stored in JPEG format with red, green, and blue (RGB) digital numbers (DNs) for each pixel in the image. Raw image format can also be used, which is discussed in detail by Richardson et al. (2013b) and Brown et al. (2016). Variability in scene illumination can affect the 

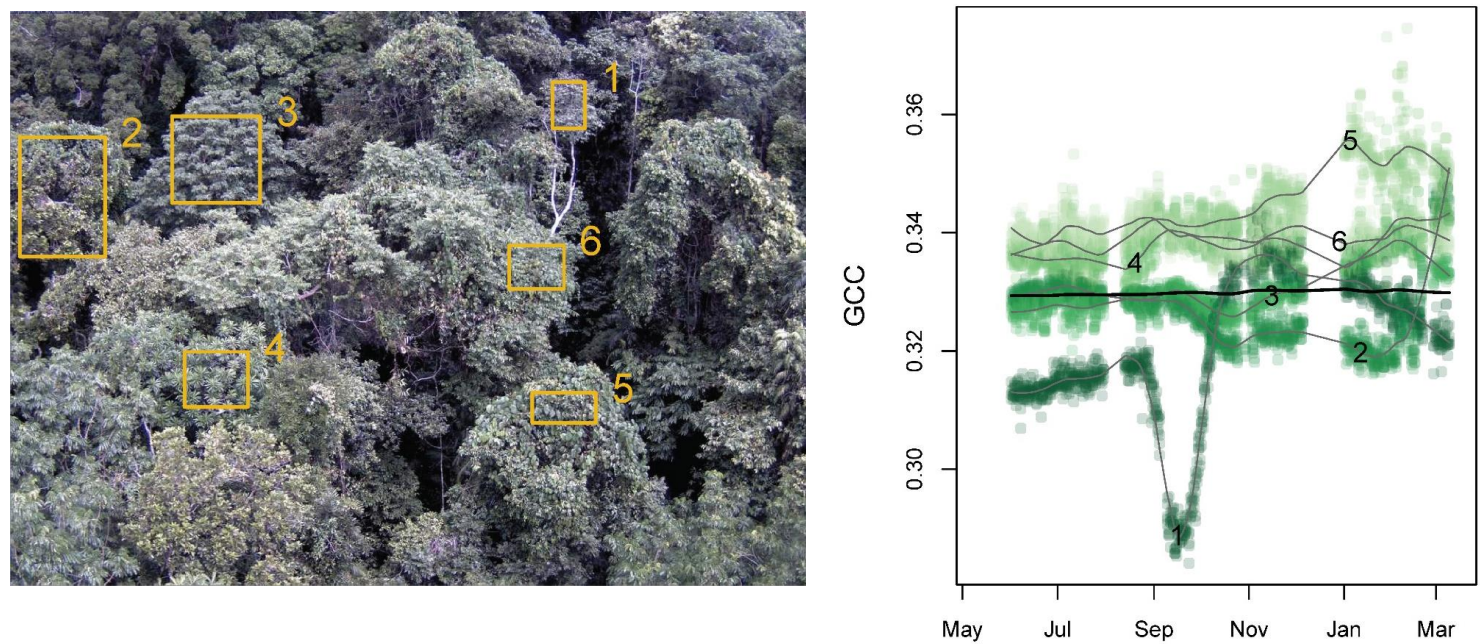

Figure 3. Green chromatic coordinates (GCC) for six individual tree crowns (indicated by orange regions of interest) at the Cow Bay tropical rainforest OzFlux site (Fig. 2; site 1, AU-Cow), Queensland, Australia. Leaf shedding and flushing events (note especially Tree 1, Wrightia laevis, and Tree 2, Acmena graveolens) are highly specific to individual trees. Black line represents GCC from the full camera field of view. See Fig. 4 for example region of interest variability over time.

RGB brightness levels (Woebbecke et al., 1995; Richardson et al., 2007), which can be minimised by using a transformation of the RGB numeric values to chromatic coordinates (Gillespie et al., 1987; Woebbecke et al., 1995; Sonnentag et al., 2012). Of these indices, the green chromatic coordinate (GCC) has been identified as the most relevant to green vegetation phenology, given by Eq. (2):

$\mathrm{GCC}=G /(R+G+B)$,

where $R, G$, and $B$ are the per-pixel DNs stored in the image, recorded as arbitrary units of intensity by the camera's charge-coupled device. GCC is calculated for each pixel of the image and then averaged over a user-defined region of interest (ROI). The red (RCC) and blue (BCC) chromatic coordinates were also calculated, in the same way as GCC in Eq. (2). We calculated chromatic coordinates using only images collected between the hours of 10:00 and 16:00, based on local site time, to reduce the bias of seasonal solar radiation change on the "daily" values, which is a common phenocam analysis technique (Sonnentag et al., 2012; Filippa et al., 2016).

An advantage of being able to transform the phenocam images into these quantitative indices is that it allows for automated quality control of the data. This is important when a large network of automated measurements is being considered on a continental and global scale (Brown et al., 2016). Automated quality assurance and quality control (QA/QC) routines are regularly used for large-scale processing of other network data, including ecosystem flux data such as OzFlux (Beringer et al., 2016; Isaac et al., 2016) and continental-scale observatories such as NEON (Taylor and Loescher, 2013) and the Terrestrial Ecosystem Research
Network (TERN; Karan et al., 2016). Furthermore, these automated routines can allow for the fast calculation of online summary metrics that can be used for diagnosing instrument problems and highlighting potential flaws in data collection (Smith et al., 2014). As a result, instrument downtime can be minimized and data collection can be optimized across a large network of sensors.

\subsection{Insights from existing phenocams}

To demonstrate the utility of phenocams for monitoring in situ vegetation phenology in Australian ecosystems, we calculated GCC from image data sets from four contrasting ecosystems in Australia: Cow Bay (AU-Cow, Fig. 2; site 1), Howard Springs (AU-How, Fig. 2; site 2), Tumbarumba (AUTum, Fig. 2; site 3), and Whroo (AU-Whr, Fig. 2; site 6). We used R software (R Core Team, 2013) to extract and calculate chromatic coordinates (Eq. 2) from phenocam images collected between the hours of 10:00 and 16:00 at local site time (i.e. UTC $+10: 00$ or 9:30 h). Temporal coverage varied for each camera, so we analysed all available images within the 10:00 to $16: 00$ time frame and calculated a daily average value of GCC, RCC, and BCC.

\subsubsection{Tropical rainforest}

In the EVI phenology map, the Daintree tropical rainforest region (Fig. 2b) displays constantly high EVI, as greenness varies little throughout the year compared with other sites. Overstorey phenology at the evergreen Cow Bay rainforest OzFlux site (AU-Cow) showed that GCC of the entire tree canopy was not seasonally dynamic either (Fig. 3). However, six individual tree crowns selected as ROIs and 
analysed individually revealed a more dynamic variability in GCC (Fig. 3), which fluctuated in line with leaf shedding and flushing events in some trees (Tree 1, species Wrightia laevis, and Tree 2, Acmena graveolens) or remained relatively constant in others (Tree 3, Dysoxylum alliaceum, and Tree 4, Cerbera floribunda). These events were determined via visual inspection of images that clearly revealed leaf loss (Fig. 4). Species-rich ecosystems can include a wide range of phenologies (Wright and van Schaik, 1994; Reich et al., 2004) that become indistinguishable when averaged over the entire ecosystem. In contrast to temperate deciduous and boreal ecosystems in the Northern Hemisphere, where seasonal dynamics of the canopy are largely temperature-controlled, the changes evident from Cow Bay suggest that the different species respond to a variety of cues, resulting in an apparent evergreen canopy despite significant individual phenological variability (Wu et al., 2016).

Tropical rainforests in nearby south-east Asia often show little or no clear seasonal dynamics in canopy cover and productivity (Kho et al., 2013) but are well known for synchronous mast fruiting with a return frequency of around 210 years (Visser et al., 2011). The general flowering in these forests that is associated with these mast fruiting events has been shown to be triggered by irregular droughts (Sakai et al., 2006). More recently, phenocams have been used to analyse the phenology of a dipterocarp canopy, a forest type associated with mast events in Borneo (Nagai et al., 2016). This study confirmed that indices such as \% RGB and GCC can be used to track flowering and leaf flushing at the individual tree level.

Less understood are similar "masting" events in the forests of the wet tropics of north Queensland (M. Bradford, personal communication, 2015). These masting events occur with a return frequency of around 7 years, and the trigger appears to be drier-than-normal conditions. Another characteristic of the Wet Tropics area is cyclone activity during the wet season, where the coastal forests are known colloquially as "cyclone scrub". The return frequency of low-intensity cyclones is around 5 years (Australian system: category 1 for a coastal crossing) while more intense cyclones have longer return frequencies (Turton and Stork, 2008). To date, no longterm phenology studies have been published for the rainforests of Far North Queensland (FNQ). The combination of phenocams and weather stations on the Cow Bay (AUCow), Cape Tribulation (AU-Ctr), and Robson Creek (AURob) OzFlux towers, all parts of the FNQ Rainforest SuperSite (Fig. 2), will allow the timing and the drivers of synchronous masting events and effects of cyclone activity to be studied in detail over the next few decades.

To highlight the utility of phenocams for identifying individual phenological variability in FNQ, we looked at one of the trees (Tree 1,W. laevis, the most variable tree in Fig. 3) in more detail (Fig. 4). When leaf shedding occurred, GCC rapidly decreased with an associated rapid increase in BCC, which is reflective of the change from green foliage to blue- tinged bare woody components. The analysis also showed a slower rate of leaf flushing compared to the swift leaf fall event. At the onset to the rapid decrease in GCC, RCC increased markedly (Fig. 4). This increase in redness may be due to the build-up of anthocyanin pigments that cause the red colouration of senescing leaves, also a distinct feature of deciduous forest canopies in autumn (Hoch et al., 2001; Lee et al., 2003; Gould, 2004). This species, W. laevis, may be found further north in semi-deciduous and deciduous vegetation communities that are connected floristically to the rainforests of the Daintree region. The leaf phenology of the species is not described in the literature (to our knowledge); however, a recent useful reference on similar leaf phenology in tropical rainforest species may be found in $\mathrm{Wu}$ et al. (2016). The vegetation types found at the Cow Bay site, and wider Daintree region (Fig. 2), experience monsoondriven seasonality, so it would seem likely that the deciduous character displayed by $W$. laevis is an adaptive advantage for these plant communities. The GCC, RCC, and BCC responses show that phenocams can capture leaf reddening and leaf fall at fine spatial and temporal resolution, thereby opening up opportunities for understanding the causes and effects of such changes in more detail.

\subsubsection{Tropical savanna}

Unlike the constantly high EVI of Australia's tropical rainforests, savannas display seasonally dynamic EVI on the regional scale (Fig. 2a). Extraction of GCC for understorey images revealed a strong seasonal phenological response at the Howard Springs site, evident by a sharp increase in GCC at the onset of the wet season (i.e. October-November, Fig. 5). In contrast, similar comparison of these indices for the overstorey images showed that overstorey dynamics varied much less than those of the understorey (Fig. 5). Therefore, the seasonality in EVI (Fig. 2a) is primarily driven by the highly seasonally dynamic growth of the $C_{4}$ grassy understorey and less by the comparatively consistent evergreen overstorey tree canopy. Fractional overstorey cover at Howard Springs is approximately $50 \%$ (Kanniah et al., 2009), and while the understorey is homogenous on the landscape scale, it can vary on the phenocam scale (i.e. field of view (FOV) of several metres; Moore et al., 2016). To account for this, GCC was calculated from four phenocams installed at the site and averaged to obtain a single daily GCC estimate.

There are two main strategies employed by plants growing in seasonally dry savannas; drought avoidance through deciduous or dieback (i.e. annual/perennial) phenology and drought tolerance through evergreen phenology (Williams et al., 1997; Tomlinson et al., 2013). We observed both strategies, as annual grasses displayed a boom-bust cycle in GCC, whereas the eucalypt-dominated overstorey maintained its leaf cover without major variability in GCC. However, the savanna overstorey at this site also includes a small portion (ca. $20 \%$ ) of semi-, brevi-, and fully deciduous species that 


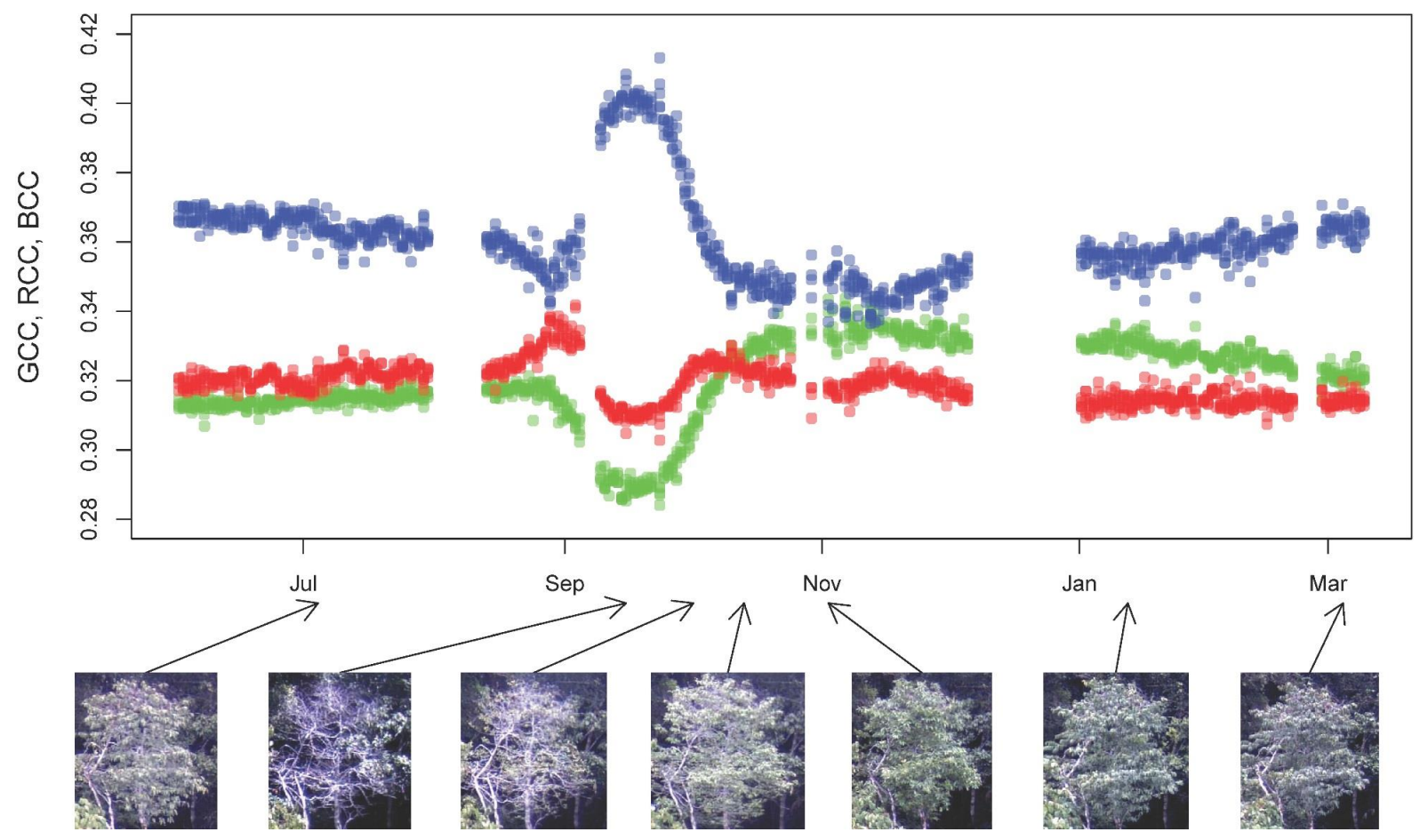

Figure 4. Green (GCC), red (RCC), and blue (BCC) chromatic coordinates for a single tree (Wrightia laevis) at the Cow Bay tropical rainforest OzFlux site (Fig. 2; site 1, AU-Cow), Queensland, Australia. Quick leaf shedding and flushing events are well captured by the phenocam.

shed their leaves primarily in the dry season (i.e. mid Aprilmid October; Williams et al., 1997; Hutley et al., 2011). The phenocams at this site did not capture these species, highlighting the need to consider phenocam positioning and FOV when installing in complex ecosystems.

The strong seasonal changes seen in the understorey (Fig. 5) are a characteristic phenological response of savanna grasses to the onset of the dry season (i.e. April-May). Each year, the commencement of the dry season triggers understorey $C_{4}$ grass senescence (Andrew and Mott, 1983) and canopy leaf fall (Williams et al., 1997) as the plants prepare to survive through the rainless months of May to September (Cook and Heerdegen, 2001). This phenological change results in a transition from green to brown in the understorey, as evidenced by reduced GCC and a reduction in savanna GPP (Whitley et al., 2011; Ma et al., 2013; Moore et al., 2016).

The reduction in leaf water content associated with senescence also causes an increase in fire susceptibility. During the dry season, the senesced understorey is consumed in fire events at 1-5-year intervals (Beringer et al., 2015). Fire can affect phenology in the short term through its impact on canopy area (Cernusak et al., 2006; Beringer et al., 2007) and over longer timescales through feedbacks to plant demography (Beringer et al., 2011; Werner and Franklin, 2010; Werner and Prior, 2013). In addition to fire, cyclone activity can disturb Australia's savannas, with wind throw from severe tropical storms resulting in patches of defolia- tion (roughly every 5 years) and extreme cyclones causing up to complete destruction (once every 500-1000 years; Hutley et al., 2013). In Australian savannas, pronounced spatiotemporal variability exists in this phenology, which still requires further examination in fine detail so it can be more accurately understood (Ma et al., 2013). The coupling of phenocam imagery with MODIS phenology information (i.e. EVI) may assist in exploring the effects of disturbance in more detail, and whilst outside the scope of this study, it offers exciting opportunities for future research.

\subsubsection{Temperate evergreen forest}

We calculated GCC for the Tumbarumba OzFlux site (AUTum), a wet (i.e. high rainfall) temperate evergreen forest that represents another key Australian biome. Two phenocams were installed at this site: one on the flux tower at $60 \mathrm{~m}$ with a nadir view angle (i.e. TimeLapseCam, Wingscapes, Calera, AL, USA) and the other at $1.5 \mathrm{~m}$ with an oblique view angle (i.e. Raspberry Pi RGB camera, Raspberry Pi Foundation, UK). As a result, the cameras measured different ROIs. Despite the differences in orientation and view, GCC values from both phenocams at Tumbarumba clearly increased from November 2014 to January 2015, showing a flush of the understorey leading into summer (Fig. 6).

For wet temperate evergreen ecosystems in Australia, like the forest at Tumbarumba, flushing events in summer are a 


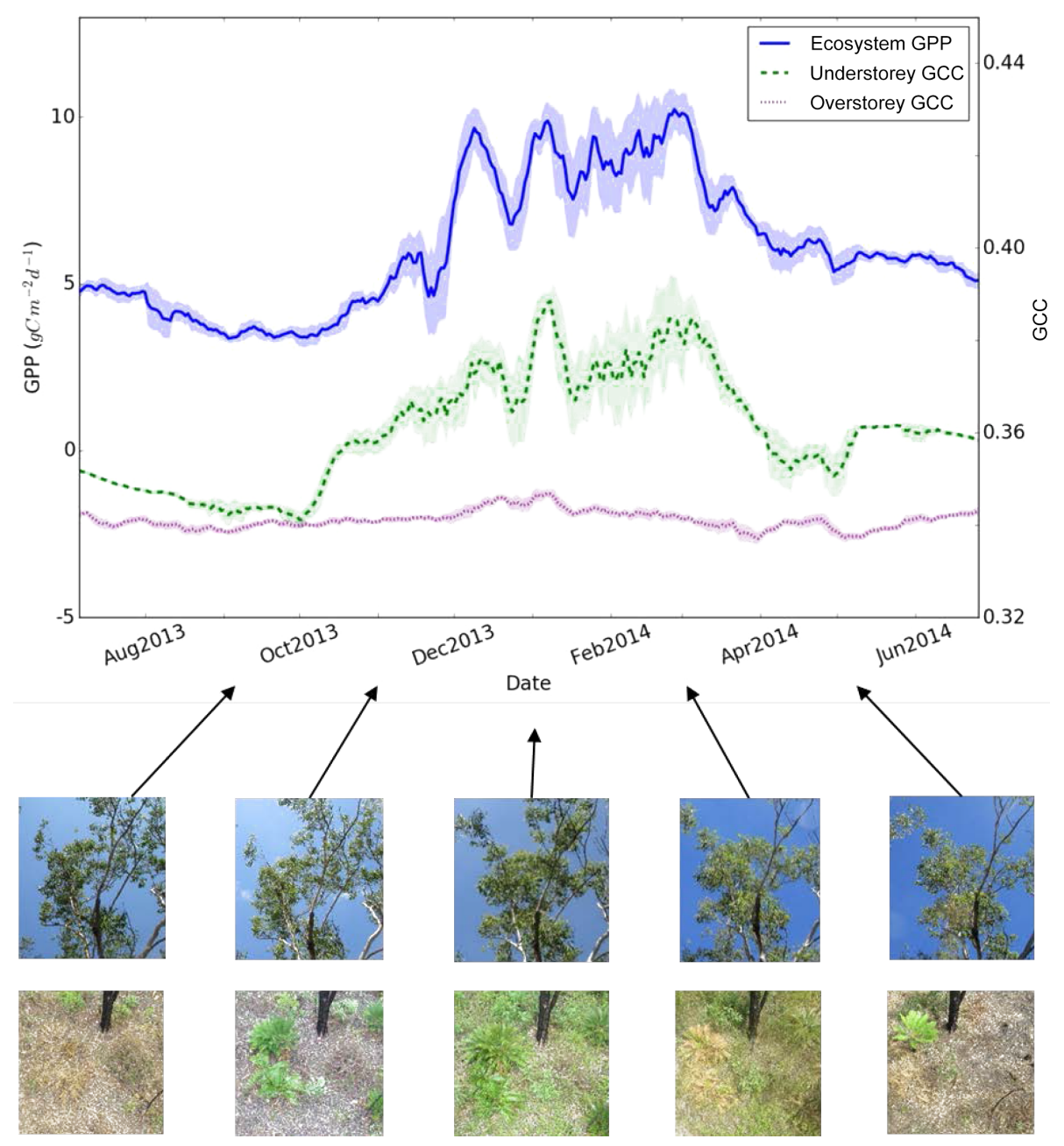

Figure 5. Ecosystem gross primary productivity (GPP) and green chromatic coordinates (GCC) for the overstorey and understorey, with region of interest (ROI) image examples, at the Howard Springs tropical savanna OzFlux site (Fig. 2; site 2, AU-How), Northern Territory, Australia. Data are shown as an 8-day centred running mean with $\pm 90 \%$ confidence shading.

common occurrence (Restrepo-Coupe et al., 2015), as temperature and light tend to be the primary drivers of phenology, with water availability a secondary factor (van Gorsel et al., 2013; Rawal et al., 2014). Tumbarumba is situated in a subalpine zone where winter minimum temperatures often drop below zero, with occasional snow events (van Gorsel et al., 2013). Low temperature and incoming solar radiation in winter result in reduced vegetation cover and activity in alpine and subalpine regions, whereas increased radiation and temperature in summer promote rates of vegetation emergence, flowering, and cover (Law et al., 2000; Venn and Morgan, 2007; Green, 2010). A recent study from Rawal et al. (2014), looking at environmental effects on eucalypt phenology, found that photoperiod length and temperature were key variables controlling the growth rates of several eucalypt species in wet and dry temperate evergreen forests in south-eastern Australia. While this notion holds true for wet temperate forests such as Tumbarumba (Keith et al., 2012; van Gorsel et al., 2013), water availability increases in importance as a phenology driver in dry temperate forests (Rawal et al., 2014; Duursma et al., 2016). Continued phenocam monitoring at Tumbarumba and other dry temperate sites (i.e. Whroo (site 6) and Cumberland Plain (site 12); Fig. 2), as well as the addition of more cameras in wet and dry temperate forests, will improve our understanding of the phenological processes occurring at temperate evergreen sites over longer timescales in Australia.

\subsection{Phenocams and ecosystem productivity}

Whilst phenocams are clearly useful for identifying finescale phenological changes in terrestrial ecosystems often missed by larger-scale satellite indices, the extracted indices can also provide a useful comparison with productivity estimates, such as GPP. Toomey et al. (2015) compared phenocam-derived GCC to eddy-covariance-derived 


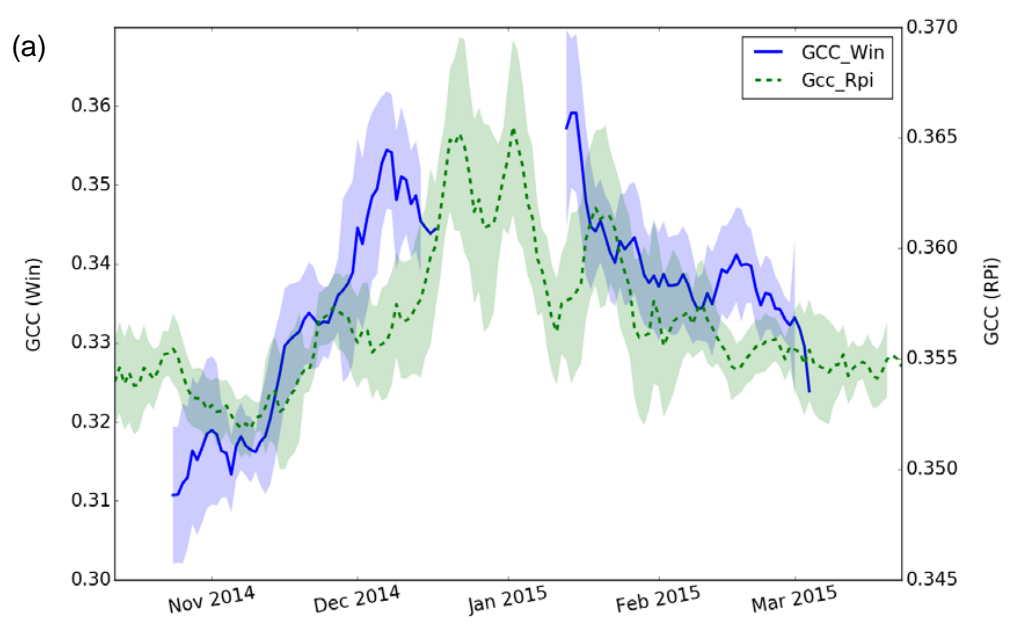

(b)
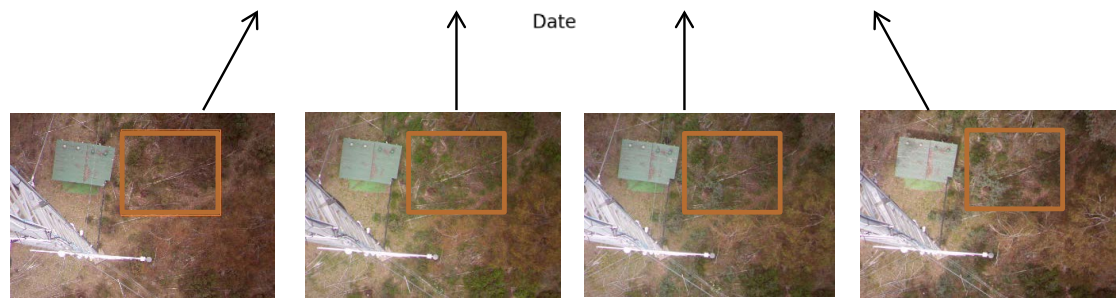

(c)
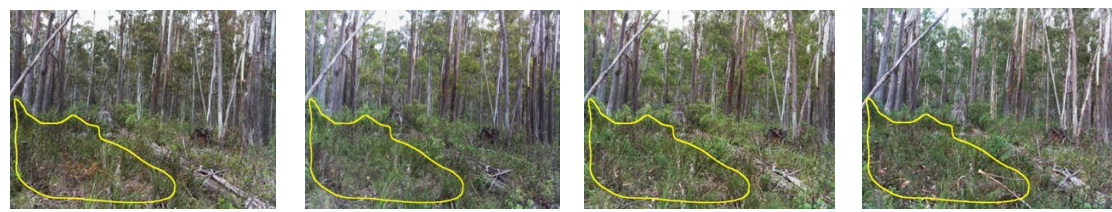

Figure 6. Phenocams in use at the Tumbarumba wet temperate OzFlux site (Fig. 2; site 3, AU-Tum), New South Wales, Australia. Panel (a) shows green chromatic coordinates (GCC) for understorey vegetation from two individual understorey phenocams; (b) shows a downward facing TimeLapseCam Wingscapes (GCC_Win) phenocam (region of interest inset) and (c) an oblique facing raspberry pi (GCC_Rpi) phenocam (region of interest inset). GCC data are shown by an 8-day centred running mean with $\pm 90 \%$ confidence shading.

estimates of GPP at several sites within North America and Canada and found correlations between some ecosystem GCC indices and GPP. They concluded that phenocams can be a valuable tool for independently verifying variability in GPP attributable to phenology. To demonstrate the potential of this idea for Australian ecosystems, we plotted GPP data from two contrasting Australian ecosystems against phenocam-derived GCC. At the first site, Howard Springs tropical savanna (GPP data from Moore et al., 2016), GCC varied in line with GPP, both of which reached a maximum at the peak of the wet season (Fig. 5). The GCC signal rapidly decreases once the predominant understorey grasses senesce at the end of the wet season and is also reflected by a reduction in GPP (Fig. 5). Whitley et al. (2011) attributed increased LAI in the understorey to the rapid increase in savanna GPP. Likewise, Moore et al. (2016) attribute the seasonal dynamics of savanna GPP to be largely determined by understorey flushing, with a more steady contribution from the overstorey throughout the year. Fig. 5 supports the conclusions of Whitley et al. (2011) and Moore et al. (2016) as it shows a much more dynamic understorey when compared with the overstorey, the cycles of which are reflected in the ecosystem GPP estimate.

At the second site, Whroo dry temperate evergreen woodland (GPP data from, Beringer et al., 2016), GCC and GPP did not track each other over time like at Howard Springs (Fig. 7). While GCC remains relatively constant, there is a clear growing season displayed by GPP in the summer months (i.e. December-February; Fig. 7). In evergreen ecosystems such as Whroo, productivity is driven more by vegetation responses to meteorological drivers (i.e. solar radiation, air temperature, rainfall) rather than to phenological variability (Restrepo-Coupe et al., 2015). LAI at Whroo is maintained at approximately $1.0 \mathrm{~m}^{2} \mathrm{~m}^{-2}$ throughout the year (I. McHugh, personal communication, 2015), and being evergreen in nature, the phenocam is not able to discern phenological variability related to greenness on the ecosystem scale. For temperate evergreen ecosystems in Australia, phenocams are not as useful for linking with GPP (Restrepo- 


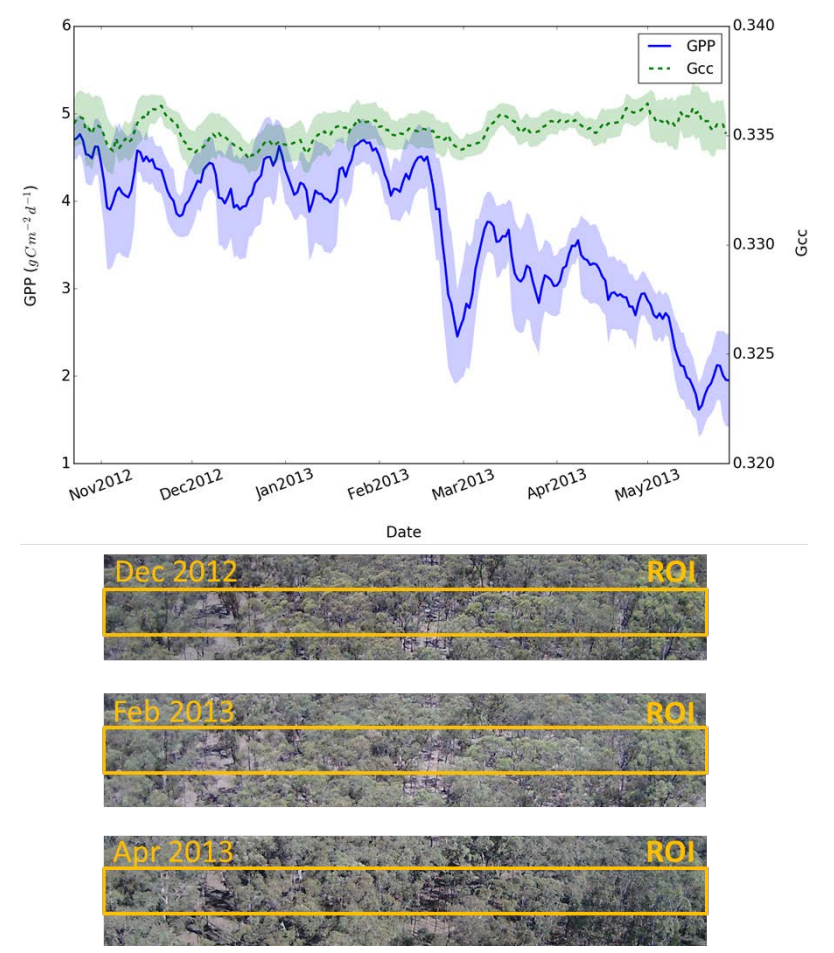

Figure 7. Ecosystem gross primary productivity (GPP) and green chromatic coordinate (GCC) index for the Whroo dry temperate OzFlux site (Fig. 2; site 6, AU-Whr) in south-eastern Victoria, Australia. Both GPP and GCC data are shown by an 8-day centred running mean with $\pm 90 \%$ confidence shading. The region of interest (ROI) for GCC calculation is indicated by the orange box in the three images that represent different times throughout the year.

Coupe et al., 2015) but still likely hold value for identifying individual phenology signals within the evergreen canopy.

\section{Expanding the Australian Phenocam network}

We have shown the value of phenocams for ecosystem monitoring in Australia and how they can be used to inform on species-level changes, supplement large-scale satellite remote sensing data, and aid in interpreting ecosystem GPP. In Australia, phenocams have primarily been installed at several pre-existing TERN supported OzFlux sites (http://www. ozflux.org.au/), at which eddy covariance flux towers are used to study carbon, water, and energy exchanges between ecosystems and the atmosphere. Phenocams are currently being deployed across TERN and the Australian SuperSite Network (http://www.tern-supersites.net.au), where a comprehensive set of co-located measurements of vegetation, faunal biodiversity, soil or water, and remote sensing is being made. Despite these recent deployments, the spatial and temporal coverage of phenocams in Australia remains limited (Fig. 2).

Several of the phenocams in Australian ecosystems are either in the early stages of operation or have experienced issues with long-term stability in data collection (i.e. FOV shifts, lack of timestamp standards, loss of data), and some ecosystems in Australia are missing altogether (i.e. alpine ecosystems, managed agricultural land, mangroves; Fig. 2). Phenocams are one of few observing methods that can bridge across spatial and temporal scales, from individual plants to the ecosystem and continental scales and between biophysical function and ecological condition and composition. They can capture seasonal trends (Figs. 5, 6, and 7) and shortlived events (Figs. 3, 4) that are often missed by coarserscale techniques (i.e. satellite sensors; Fig. 2). As such, the establishment of a national phenocam network in Australia will be an extremely valuable contribution to help integrate data products between TERN facilities addressing different ecosystem questions on different scales (i.e. the SuperSites, OzFlux, LTERN, AusCover, and eMAST).

\section{Data standardisation and sharing}

Standardisation and quality control in phenocam data collection is essential to support cross-site and cross-ecosystem comparisons. There is a clear need for standards in measurement in Australia, with a wide range of phenocam hardware currently in use. Brown et al. (2016) provide recommendations for improving phenocam datasets and improving comparability between sites, including

- maintaining metadata and data management standards (i.e. image naming, FOV, camera settings) for all camera-based data

- registering all publicly available phenocams with a regional phenocam network

- making datasets available online wherever possible.

Analysis of some of the datasets revealed that camera quality and installation issues (i.e. sun glare, inappropriate image acquisition times, power consumption) play a role in data quality. However, the single greatest challenge was found to be changes in data quality and characteristics over time that limit or prevent automated analysis. In particular, changes in the FOV over time due to intentional or unintentional reorientation of the camera create a major obstacle to the collection of a sufficiently long time series and to automated data analysis. Slight or gradual changes can be dealt with through additional image co-registration efforts, but they can be arduous and reduce the area effectively available for analysis. Solid mounting of the camera and, when necessary, accurate realignment after removal (i.e. for maintenance) or unintentional reorientation can help alleviate such issues. Maintaining a consistent FOV is critical. For all but the most homogeneous environments, the FOV of the phenocam is the dataset. Each time the camera moves, the usable pixels for which there are long-term monitoring data become increasingly constrained. 
Data publication and sharing are also important factors to consider. We have formed the Australian Phenocam Network (http://phenocam.org.au/) to provide a platform for phenocam data sharing, storage, and publication to the wider scientific community. This network is continually evolving, with data made available under the TERN "By Attribution" license based on the Creative Commons framework (http:// www.tern-supersites.net.au). As for other national and global multi-site data sets, open access to phenocam data will enhance the reproducibility and extensibility of research and the combined value of such data (Brown et al., 2016).

\section{Conclusions}

We see considerable potential for the developing Australian Phenocam Network. Existing infrastructure, supported by TERN, will assist in the establishment of this network, the implementation of more phenocams around the country, and the standardisation of data collection, analysis, and sharing. The Australian Phenocam Network would also provide valuable data for monitoring networks such as OzFlux, SuperSites, AusPlots, and eMAST. Currently, there are only a small number of continuously operating phenocams in Australia, with even fewer uploading data to the Australian phenocam website. Expansion of the currently sparse distribution of Australian phenocams will help improve our understanding of the diversity of phenological strategies employed by Australian ecosystems. Combined with satellite remote sensing techniques, phenocams can improve our ability to quantify and predict the functioning of Australia's ecosystem within the Earth system.

\section{Data availability}

The Australian phenology map (Fig. 2) was constructed using freely available MODIS EVI data (2000-2012) obtained from the Oak Ridge National Laboratory Distributed Active Archive Center (https://daac.ornl.gov/MODIS/). The eddy covariance data used in this manuscript are also freely available from the OzFlux data portal (http://ozflux.org.au). Howard Springs flux data are provided to this database by Beringer (2013a) and Whroo data by Beringer (2013b). Likewise, the phenocam data are freely available through the recently formed Australian Phenocam Network (https: //phenocam.org.au).

Author contributions. This paper was conceived and outlined at the ACEAS 2014 Phenocam Workshop led by T. Brown and T. F. Keenan. C. E. Moore created the first draft and was the primary editor for subsequent drafts. T. F. Keenan and T. Brown provided oversight and additional edits. All authors provided additional text, edits, and review. J. Liddell provided data for the Cow Bay analysis, A. I. J. M. van Dijk provided analysis of the remote sensing data, and R. A. Duursma provided primary analysis for the Cow
Bay and Tumbarumba data. C. E. Moore provided data and analysis for Howard Springs, and D. Culvenor provided data for Tumbarumba. N. Restrepo-Coupe provided data and analysis for Cow Bay, Whroo, and Tumbarumba dataset. Figure credits: 1: B. Evans and C. E. Moore; 2: A. I. J. M. van Dijk and C. E. Moore; 3 and 4: R. A. Duursma; 5: C. E. Moore; 6: D. Culvenor and C. E. Moore; 7: C. E. Moore and N. Restrepo-Coupe.

Acknowledgements. First and foremost, the authors would like to acknowledge the Australian Centre for Ecological Analysis and Synthesis (ACEAS) for their support of a workshop aimed at developing a Phenocam Network in Australia, held on Stradbroke Island in March 2014. Support for collection and archiving of some of the data used in this paper was provided through the Australian Government Terrestrial Ecosystem Research Network (TERN) (http://www.tern.org.au) facilities ACEAS, AusCover, SuperSites, OzFlux, and eMAST. Part of the data was also funded via Australian Research Council grants DP0772981 and DP130101566. J. Beringer is funded under an ARC Future Fellowship (FT1110602). T. F. Keenan acknowledges support from a Macquarie University Research Fellowship. Tumbarumba cameras were funded by a Re-establishment Grant 2013 from the University of Technology Sydney: "Setup of a phenocam network on some key Australian ecosystems" (N. Restrepo-Coupe, CI). C. E. Moore also personally thanks Matthew Northwood, from Charles Darwin University, for his assistance with the Howard Springs phenocams.

Edited by: M. Migliavacca

Reviewed by: two anonymous referees

\section{References}

Ahrends, H. E., Etzold, S., Kutsch, W. L., Stoeckli, R., Bruegger, R., Jeanneret, F., Wanner, H., Buchmann, N., and Eugster, W.: Tree phenology and carbon dioxide fluxes: Use of digital photography for process-based interpretation at the ecosystem scale, Clim. Res., 39, 261-274, 2009.

Andela, N., Liu, Y. Y., van Dijk, A. I. J. M., de Jeu, R. A. M., and McVicar, T. R.: Global changes in dryland vegetation dynamics (1988 to 2008) assessed by satellite remote sensing: comparing a new passive microwave vegetation density record with reflective greenness data, Biogeosciences, 10, 6657-6676, doi:10.5194/bg10-6657-2013, 2013.

Andrew, M. H. and Mott, J. J.: Annuals with transient seed banks: the population biology of indigenous Sorghum species of tropical north-west Australia, Aust. J. Ecol., 8, 265-276, 1983.

Barry, K., Corkrey, R., Stone, C., and Mohammed, C.: Characterizing eucalypt leaf phenology and stress with spectral analysis, in: Innovations in Remote Sensing and Photogrammetry, Lecture Notes in Geoinformation and Cartography, edited by: Jones, S. and Reinke, K., Springer, Berlin Heidelberg, 193-209, 2009.

Beringer, J., Hutley, L. B., Tapper, N. J., and Cernusak, L. A.: Savanna fires and their impact on net ecosystem productivity in North Australia, Glob. Change Biol., 13, 990-1004, 2007.

Beringer, J., Hacker, J., Hutley, L. B., Leuning, R., Arndt, S. K., Amiri, R., Bannehr, L., Cernusak, L. A., Grover, S., Hensley, 
C., Hocking, D., Isaac, P., Jamali, H., Kanniah, K., Livesley, S., Neininger, B., Paw U, K. T., Sea, W., Straten, D., Tapper, N., Weinmann, R., Wood, S., and Zegelin, S.: Special - Savanna patterns of energy and carbon integrated across the landscape, B. Am. Meteorol. Soc., 92, 1467-1485, 2011.

Beringer, J.: Howard Springs OzFlux tower site OzFlux: Australian and New Zealand Flux Research and Monitoring hdl, doi:102.100.100/14234, 2013a.

Beringer, J.: Whroo OzFlux tower site OzFlux: Australian and New Zealand Flux Research and Monitoring hdl, doi:102.100.100/14232, 2013b.

Beringer, J., Hutley, L. B., Abramson, D., Arndt, S. K., Briggs, P., Bristow, M., Canadell, J. G., Cernusak, L. A., Eamus, D., Edwards, A. C., Evans, B. J., Fest, B., Goergen, K., Grover, S. P., Hacker, J., Haverd, V., Kanniah, K., Livesley, S. J., Lynch, A., Maier, S., Moore, C., Raupach, M., Russell-Smith, J., Scheiter, S., Tapper, N. J., and Uotila, P.: Fire in Australian savannas: From leaf to landscape, Glob. Change Biol., 21, 62-81, 2015.

Beringer, J., Hutley, L., McHugh, I., Arndt, S., Campbell, D., Cleugh, H., Cleverly, J., Resco de Dios, V., Eamus, D., Evans, B., Ewenz, C., Grace, P., Griebel, A., Haverd, V., Hinko-Najera, N., Isaac, P., Kanniah, K., Leuning, R., Liddell, M., Macfarlane, C., Meyer, W., Moore, C., Pendall, E., Phillips, A., Phillips, R., Prober, S., Restrepo-Coupe, N., Rutledge, S., Schroder, I., Silberstein, R., Southall, P., Sun, M., Tapper, N., van Gorsel, E., Vote, C., Walker, J., and Wardlaw, T.: An introduction to the Australian and New Zealand flus tower network - OzFlux, Biogeosciences Discuss., doi:10.5194/bg-2016-152, in review, 2016.

Bowman, D. M. J. S.: Australian Rainforests : Islands of Green in a Land of Fire, Cambridge University Press, Cambridge, 2000.

Broich, M., Huete, A., Tulbure, M. G., Ma, X., Xin, Q., Paget, M., Restrepo-Coupe, N., Davies, K., Devadas, R., and Held, A.: Land surface phenological response to decadal climate variability across Australia using satellite remote sensing, Biogeosciences, 11, 5181-5198, doi:10.5194/bg-11-5181-2014, 2014.

Broich, M., Huete, A., Paget, M., Ma, X., Tulbure, M., Coupe, N. R., Evans, B., Beringer, J., Devadas, R., Davies, K., and Held, A.: A spatially explicit land surface phenology data product for science, monitoring and natural resources management applications, Environ. Modell. Software, 64, 191-204, 2015.

Brown, T. B., Hultine, K. R., Steltzer, H., Denny, E. G., Denslow, M. W., Granados, J., Henderson, S., Moore, D., Nagai, S., and SanClements, M.: Using phenocams to monitor our changing Earth: toward a global phenocam network, Front. Ecol. Environ., 14, 84-93, 2016.

Burrows, G. E.: Syncarpia and Tristaniopsis (Myrtaceae) possess specialised fire-resistant epicormic structures, Aust. J. Bot., 56, 254-264, 2008.

Cernusak, L. A., Hutley, L. B., Beringer, J., and Tapper, N. J.: Stem and leaf gas exchange and their responses to fire in a north Australian tropical savanna, Plant, Cell Environ., 29, 632-646, 2006.

Chambers, L. E., Altwegg, R., Barbraud, C., Barnard, P., Beaumont, L. J., Crawford, R. J. M., Durant, J. M., Hughes, L., Keatley, M. R., Low, M., Morellato, P. C., Poloczanska, E. S., Ruoppolo, V., Vanstreels, R. E. T., Woehler, E. J., and Wolfaardt, A. C.: Phenological Changes in the Southern Hemisphere, PLoS ONE, 8, e75514, doi:10.1371/journal.pone.0075514, 2013.

Cleverly, J., Eamus, D., Van Gorsel, E., Chen, C., Rumman, R., Luo, Q., Coupe, N. R., Li, L., Kljun, N., Faux, R., Yu, Q., and
Huete, A.: Productivity and evapotranspiration of two contrasting semiarid ecosystems following the 2011 global carbon land sink anomaly, Agr. Forest Meteorol., 220, 151-159, 2016.

Close, D. C., Beadle, C. L., Brown, P. H., and Holz, G. K.: Cold-induced photoinhibition affects establishment of Eucalyptus nitens (deane and maiden) maiden and Eucalyptus globulus labill, Trees, Struct. Funct., 15, 32-41, 2000.

Close, D. C., Beadle, C. L., and Hovenden, M. J.: Cold-induced photoinhibition and foliar pigment dynamics of Eucalyptus nitens seedlings during establishment, Aust. J. Plant Physiol., 28, 1133-1141, 2001a.

Close, D. C., Davies, N. W., and Beadle, C. L.: Temporal variation of tannins (galloylglucoses), flavonols and anthocyanins in leaves of Eucalyptus nitens seedlings: Implications for light attenuation and antioxidant activities, Aust. J. Plant Physiol., 28, 269-278, 2001b.

Close, D. C. and Beadle, C. L.: The Ecophysiology of Foliar Anthocyanin, Bot. Rev., 69, 149-161, 2003.

Cook, G. D. and Heerdegen, R. G.: Spatial variation in the duration of the rainy season in monsoonal Australia, Int. J. Climatol., 21, 1723-1732, 2001.

Coops, N. C., Stone, C., Culvenor, D. S., and Chisholm, L.: Assessment of crown condition in eucalypt vegetation by remotely sensed optical indices, J. Environ. Qual., 33, 956-964, 2004.

Davies, P. E., Harris, J. H., Hillman, T. J., and Walker, K. F.: A report on the ecological health of rivers in the Murray-Darling Basin 2004-2007, Independent Sustainable Rivers Audit GRoup for the Murray-Darling Basin Commission, Canberra, 2008.

de Jong, R., Verbesselt, J., Schaepman, M. E., and de Bruin, S.: Trend changes in global greening and browning: Contribution of short-term trends to longer-term change, Glob. Change Biol., 18, 642-655, 2012.

Donohue, R. J., McVicar, T. R., and Roderick, M. L.: Climaterelated trends in Australian vegetation cover as inferred from satellite observations, 1981-2006, Glob. Change Biol., 15, 10251039, 2009.

Donohue, R. J., Roderick, M. L., McVicar, T. R., and Farquhar, G. D.: Impact of $\mathrm{CO} 2$ fertilization on maximum foliage cover across the globe's warm, arid environments, Geophys. Res. Lett., 40, 3031-3035, 2013.

Dragoni, D., Schmid, H. P., Wayson, C. A., Potter, H., Grimmond, C. S. B., and Randolph, J. C.: Evidence of increased net ecosystem productivity associated with a longer vegetated season in a deciduous forest in south-central Indiana, USA, Glob. Change Biol., 17, 886-897, 2011.

Duursma, R. A., Gimeno, T. E., Boer, M. M., Crous, K. Y., Tjoelker, M. G., and Ellsworth, D. S.: Canopy leaf area of a mature evergreen Eucalyptus woodland does not respond to elevated atmospheric $\left[\mathrm{CO}_{2}\right]$ but tracks water availability, Glob. Change Biol., 22, 1666-1676, 2016.

Eamus, D., Chen, X., Kelley, G., and Hutley, L. B.: Root biomass and root fractal analyses of an open Eucalyptus forest in a savanna of north Australia, Aust. J. Bot., 50, 31-41, 2002.

Ellis, T. W. and Hatton, T. J.: Relating leaf area index of natural eucalypt vegetation to climate variables in southern Australia, Agr. Water Manage., 95, 743-747, 2008.

Evans, B., Stone, C., and Barber, P.: Linking a decade of forest decline in the south-west of Western Australia to bioclimatic change, Austr. Forest., 76, 164-172, 2013. 
Evans, B. J. and Lyons, T.: Bioclimatic extremes drive forest mortality in southwest, Western Australia, Climate, 1, 28-52, 2013.

Filippa, G., Cremonese, E., Migliavacca, M., Galvagno, M., Forkel, M., Wingate, L., Tomelleri, E., Morra di Cella, U., and Richardson, A. D.: Phenopix: A R package for image-based vegetation phenology, Agr. Forest Meteorol., 220, 141-150, 2016.

Ganguly, S., Friedl, M. A., Tan, B., Zhang, X., and Verma, M.: Land surface phenology from MODIS: Characterization of the Collection 5 global land cover dynamics product, Remote Sens. Environ., 114, 1805-1816, 2010.

Gehrke, P. C., Brown, P., Schiller, C. B., Moffatt, D. B., and Bruce, A. M.: River regulation and fish communities in the MurrayDarling river system, Australia, River Res. Appl., 11, 363-375, 2006.

Gillespie, A. R., Kahle, A. B., and Walker, R. E.: Color enhancement of highly correlated images. II. Channel ratio and "chromaticity" transformation techniques, Remote Sens. Environ., 22, 343-365, 1987.

Gonsamo, A. and Chen, J. M.: Improved LAI algorithm implementation to MODIS data by incorporating background, topography, and foliage clumping information, IEEE T. Geosci. Remote, 52, 1076-1088, 2014.

Gould, K. S., Markham, K. R., Smith, R. H., and Goris, J. J.: Functional role of anthocyanins in the leaves of Quintinia serrata A. Cunn, J. Exp. Bot., 51, 1107-1115, 2000.

Gould, K. S.: Nature's Swiss army knife: The diverse protective roles of anthocyanins in leaves, J. Biomed. Biotechnol., 2004, 314-320, 2004.

Green, K.: Alpine taxa exhibit differing responses to climate warming in the Snowy Mountains of Australia, J. Mt. Sci., 7, 167-175, 2010.

Hoch, W. A., Zeldin, E. L., and McCown, B. H.: Physiological significance of anthocyanins during autumnal leaf senescence, Tree Physiol., 21, 1-8, 2001.

Hodges, D. M. and Nozzolillo, C.: Anthocyanin and anthocyanoplast content of cruciferous seedlings subjected to mineral nutrient deficiencies, J. Plant Physiol., 147, 749-754, 1996.

Hodgkinson, K. C.: Sprouting success of shrubs after fire: Heightdependent relationships for different strategies, Oecologia, 115, 64-72, 1998.

Huete, A., Didan, K., Miura, T., Rodriguez, E. P., Gao, X., and Ferreira, L. G.: Overview of the radiometric and biophysical performance of the MODIS vegetation indices, Remote Sens. Environ., 83, 195-213, 2002. Hufkens, K., Friedl, M. A., Keenan, T. F., Sonnentag, O., Bailey, A., O'Keefe, J., and Richardson, A. D.: Ecological impacts of a widespread frost event following early spring leaf-out, Glob. Change Biol., 18, 2365-2377, 2012.

Hutley, L. B., Beringer, J., Isaac, P. R., Hacker, J. M., and Cernusak, L. A.: A sub-continental scale living laboratory: Spatial patterns of savanna vegetation over a rainfall gradient in northern Australia, Agr. Forest Meteorol., 151, 1417-1428, 2011.

Hutley, L. B., Evans, B. J., Beringer, J., Cook, G. D., Maier, S. W., and Razon, E.: Impacts of an extreme cyclone event on landscape-scale savanna fire, productivity and greenhouse gas emissions, Environ. Res. Lett., 8, 045023, doi:10.1088/17489326/8/4/045023, 2013.

Inoue, T., Nagai, S., Saitoh, T. M., Muraoka, H., Nasahara, K. N., and Koizumi, H.: Detection of the different characteristics of year-to-year variation in foliage phenology among deciduous broad-leaved tree species by using daily continuous canopy surface images, Ecol. Inform., 22, 58-68, 2014.

Isaac, P., Cleverly, J., McHugh, I., van Gorsel, E., Ewenz, C., and Beringer, J.: OzFlux Data: Network integration from collection to curation, Biogeosciences Discuss., doi:10.5194/bg-2016-189, in review, 2016.

Kanniah, K. D., Beringer, J., Hutley, L. B., Tapper, N. J., and Zhu, X.: Evaluation of Collections 4 and 5 of the MODIS Gross Primary Productivity product and algorithm improvement at a tropical savanna site in northern Australia, Remote Sens. Environ., 113, 1808-1822, 2009.

Karan, M., Liddell, M., Prober, S. M., Arndt, S., Beringer, J., Boer, M., Cleverly, J., Eamus, D., Grace, P., van Gorsel, E., Hero, J. M., Hutley, L., Macfarlane, C., Metcalfe, D., Meyer, W., Pendall, E., Sebastian, A., and Wardlaw, T.: The Australian Supersite Network: a continental, long-term terrestrial ecosystem observatory, Sci. Total Environ., 568, 1263-1274, doi:10.1016/j.scitotenv.2016.05.170, 2016.

Keenan, T. F., Darby, B., Felt, E., Sonnentag, O., Friedl, M., Hufkens, K., O'Keefe, J., Klosterman, S., Munger, J. W., Toomey, M., and Richardson, A. D.: Tracking forest phenology and seasonal physiology using digital repeat photography: a critical assessment, Ecol. Appl., 24, 1487-1489, 2014a.

Keenan, T. F., Gray, J., Friedl, M. A., Toomey, M., Bohrer, G., Hollinger, D. Y., Munger, J. W., O'Keefe, J., Schmid, H. P., Wing, I. S., Yang, B., and Richardson, A. D.: Net carbon uptake has increased through warming-induced changes in temperate forest phenology, Nature Climate Change, 4, 598-604, $2014 \mathrm{~b}$.

Keith, H., van Gorsel, E., Jacobsen, K. L., and Cleugh, H. A.: Dynamics of carbon exchange in a Eucalyptus forest in response to interacting disturbance factors, Agr. Forest Meteorol., 153, 6781, 2012.

Keller, M., Schimel, D. S., Hargrove, W. W., and Hoffman, F. M.: A continental strategy for the National Ecological Observatory Network, Front. Ecol. Environ., 6, 282-284, 2008.

Kho, L. K., Malhi, Y., and Tan, S. K. S.: Annual budget and seasonal variation of aboveground and belowground net primary productivity in a lowland dipterocarp forest in Borneo, J. Geophys. Res.Biogeo., 118, 1282-1296, 2013.

Klosterman, S. T., Hufkens, K., Gray, J. M., Melaas, E., Sonnentag, O., Lavine, I., Mitchell, L., Norman, R., Friedl, M. A., and Richardson, A. D.: Evaluating remote sensing of deciduous forest phenology at multiple spatial scales using PhenoCam imagery, Biogeosciences, 11, 4305-4320, doi:10.5194/bg-11-43052014, 2014.

Kumar, V. and Sharma, S. S.: Nutrient deficiency-dependent anthocyanin development in Spirodela polyrhiza L. Schleid, Biol. Plantarum, 42, 621-624, 1999.

Law, B., Mackowski, C., Schoer, L., and Tweedie, T.: Flowering phenology of myrtaceous trees and their relation to climatic, environmental and disturbance variables in northern New South Wales, Austral Ecol., 25, 160-178, 2000.

Lee, D. W., O'Keefe, J., Holbrook, N. M., and Feild, T. S.: Pigment dynamics and autumn leaf senescence in a New England deciduous forest, eastern USA, Ecol. Res., 18, 677-694, 2003.

Lieth, H.: Purposes of a Phenology Book, in: Phenology and Seasonality Modeling, edited by: Lieth, H., Ecological Studies, Springer Berlin Heidelberg, 3-19, 1974. 
Liu, Y., de Jeu, R., van Dijk, A., and Owe, M.: TRMM-TMI satellite observed soil moisture and vegetation density (1998-2005) show strong connection with El Nino in eastern Australia, Geophys. Res. Lett., 34, L15401, doi:10.1029/2007GL030311, 2007.

Liu, Y. Y., de Jeu, R. A. M., McCabe, M. F., Evans, J. P., and van Dijk, A. I. J. M.: Global long-term passive microwave satellitebased retrievals of vegetation optical depth, Geophys. Res. Lett., 38, L18402, doi:10.1029/2011GL048684, 2011.

Liu, Y. Y., van Dijk, A. I. J. M., McCabe, M. F., Evans, J. P., and de Jeu, R. A. M.: Global vegetation biomass change (1988-2008) and attribution to environmental and human drivers, Global Ecol. Biogeogr., 22, 692-705, 2013.

Lowman, M. D.: Temporal and spatial variability in insect grazing of the canopies of five Australian rainforest tree species, Aust. J. Ecol., 10, 7-24, 1985.

Ma, X., Huete, A., Yu, Q., Coupe, N. R., Davies, K., Broich, M., Ratana, P., Beringer, J., Hutley, L. B., Cleverly, J., Boulain, N., and Eamus, D.: Spatial patterns and temporal dynamics in savanna vegetation phenology across the north australian tropical transect, Remote Sens. Environ., 139, 97-115, 2013.

Ma, X., Huete, A., Moran, S., Ponce-Campos, G., and Eamus, D.: Abrupt shifts in phenology and vegetation productivity under climate extremes, J. Geophys. Res.-Biogeo., 120, 2036-2052, 2015

Maier, S. W. and Russell-Smith, J.: Measuring and monitoring of contemporary fire regimes in Australia using satellite remote sensing, in: Flammable Australia: fire regimes, biodiversity and ecosystems in a changing world., edited by: Bradstock, R. A., Gill, A. M., and Williams, R. J., CSIRO Publishing, Melbourne, 2012.

Matusick, G., Ruthrof, K. X., Brouwers, N. C., Dell, B., and Hardy, G. S. J.: Sudden forest canopy collapse corresponding with extreme drought and heat in a mediterranean-type eucalypt forest in southwestern Australia, Eur. J. For. Res., 132, 497-510, 2013.

Melaas, E. K., Friedl, M. A., and Zhu, Z.: Detecting interannual variation in deciduous broadleaf forest phenology using Landsat TM/ETM+ data, Remote Sens. Environ., 132, 176-185, 2013.

Melzer, A., Carrick, F., Menkhorst, P., Lunney, D., and St. John, B.: Overview, critical assessment, and conservation implications of koala distribution and abundance, Conserv. Biol., 14, 619-628, 2000.

Migliavacca, M., Galvagno, M., Cremonese, E., Rossini, M., Meroni, M., Sonnentag, O., Cogliati, S., Manca, G., Diotri, F., Busetto, L., Cescatti, A., Colombo, R., Fava, F., Morra di Cella, U., Pari, E., Siniscalco, C., and Richardson, A. D.: Using digital repeat photography and eddy covariance data to model grassland phenology and photosynthetic $\mathrm{CO}_{2}$ uptake, Agr. Forest Meteorol., 151, 1325-1337, 2011.

Migliavacca, M., Sonnentag, O., Keenan, T. F., Cescatti, A., O'Keefe, J., and Richardson, A. D.: On the uncertainty of phenological responses to climate change, and implications for a terrestrial biosphere model, Biogeosciences, 9, 2063-2083, doi:10.5194/bg-9-2063-2012, 2012.

Moore, C. E., Beringer, J., Evans, B., Hutley, L. B., McHugh, I., and Tapper, N. J.: The contribution of trees and grasses to productivity of an Australian tropical savanna, Biogeosciences, 13, 2387-2403, doi:10.5194/bg-13-2387-2016, 2016.

Nagai, S., Ichie, T., Yoneyama, A., Kobayashi, H., Inoue, T., Ishii, R., Suzuki, R., and Itioka, T.: Usability of time-lapse digital cam- era images to detect characteristics of tree phenology in a tropical rainforest, Ecol. Inform., 32, 91-106, 2016.

Nasahara, K. and Nagai, S.: Review: Development of an in situ observation network for terrestrial ecological remote sensing: the Phenological Eyes Network (PEN), Ecol. Res., 30, 211-223, 2015.

Nittler, L. W. and Kenny, T. J.: Effect of Ammonium to Nitrate Ratio on Growth and Anthocyanin Development of Perennial Ryegrass Cultivars1, Agron. J., 68, 680-682, 1976.

Parmesan, C.: Influences of species, latitudes and methodologies on estimates of phenological response to global warming, Glob Change Biol., 13, 1860-1872, 2007.

Peichl, M., Sonnentag, O., and Nilsson, M. B.: Bringing Color into the Picture: Using Digital Repeat Photography to Investigate Phenology Controls of the Carbon Dioxide Exchange in a Boreal Mire, Ecosystems, 18, 115-131, 2014.

Peñuelas, J., Rutishauser, T., and Filella, I.: Phenology feedbacks on climate change, Science, 324, 887-888, 2009.

Pook, E. W.: Canopy dynamics of Eucalyptus maculata Hook. III. Effects of drought, Aust. J. Bot., 33, 65-79, 1985.

Pook, E. W., Gill, A. M., and Moore, P. H. R.: Long-term variation of litter fall, canopy leaf area and flowering in a Eucalyptus maculata forest on the south coast of New South Wales, Aust. J. Bot., 45, 737-755, 1997.

R Core Team: a language and environment for statistical computing: http://www.r-project.org/ (last access: 5 February 2016), 2013.

Rawal, D. S., Kasel, S., Keatley, M. R., Aponte, C., and Nitschke, C. R.: Environmental effects on growth phenology of co-occurring Eucalyptus species, Int. J. Biometeorol., 58, 427-442, 2014.

Reich, P. B., Uhl, C., Walters, M. B., Prugh, L., and Ellsworth, D. S.: Leaf demography and phenology in Amazonian rain forest: A census of 40000 leaves of 23 tree species, Ecol. Monogr., 74, 3-23, 2004.

Restrepo-Coupe, N., Huete, A., Davies, K., Cleverly, J., Beringer, J., Eamus, D., van Gorsel, E., Hutley, L., and Meyer, W. S.: MODIS vegetation products as proxies of photosynthetic potential: a look across meteorological and biologic driven ecosystem productivity, Biogeosciences Discuss., 12, 19213-19267, doi:10.5194/bgd-12-19213-2015, 2015.

Richardson, A. D., Jenkins, J. P., Braswell, B. H., Hollinger, D. Y., Ollinger, S. V., and Smith, M. L.: Use of digital webcam images to track spring green-up in a deciduous broadleaf forest, Oecologia, 152, 323-334, 2007.

Richardson, A. D., Braswell, B. H., Hollinger, D. Y., Jenkins, J. P., and Ollinger, S. V.: Near-surface remote sensing of spatial and temporal variation in canopy phenology, Ecol. Appl., 19, 14171428, 2009a.

Richardson, A. D., Hollinger, D. Y., Dail, D. B., Lee, J. T., Munger, J. W., and O'Keefe, J.: Influence of spring phenology on seasonal and annual carbon balance in two contrasting New England forests, Tree Physiol., 29, 321-331, 2009b.

Richardson, A. D., Keenan, T. F., Migliavacca, M., Ryu, Y., Sonnentag, O., and Toomey, M.: Climate change, phenology, and phenological control of vegetation feedbacks to the climate system, Agr. Forest Meteorol., 169, 156-173, 2013a.

Richardson, A. D., Klosterman, S., and Toomey, M.: Near-surface sensor-derived phenology, in: Phenology: an integrative environmental science, edited by: Schwartz, M. D., Springer, Dordrecht, the Netherlands, 2013b. 
Sakai, S., Harrison, R. D., Momose, K., Kuraji, K., Nagamasu, H., Yasunari, T., Chong, L., and Nakashizuka, T.: Irregular droughts trigger mass flowering in aseasonal tropical forests in Asia, Am. J. Bot., 93, 1134-1139, 2006.

Semple, B., Rankin, M., Koen, T., and Geeves, G.: A Note on Tree Deaths during the Current (2001-) Drought in South-eastern Australia, Aust. Geogr., 41, 391-401, 2010.

Sharma, P. and Crowden, R.: Anthocyanins in some eucalyptus species, Aust. J. Bot., 22, 623-627, 1974.

Smith, D. E., Metzger, S., and Taylor, J. R.: A Transparent and Transferable Framework for Tracking Quality Information in Large Datasets, PLoS ONE, 9, e112249, doi:10.1371/journal.pone.0112249, 2014.

Sonnentag, O., Detto, M., Vargas, R., Ryu, Y., Runkle, B. R. K., Kelly, M., and Baldocchi, D. D.: Tracking the structural and functional development of a perennial pepperweed (Lepidium latifolium L.) infestation using a multi-year archive of webcam imagery and eddy covariance measurements, Agr. Forest Meteorol., 151, 916-926, 2011.

Sonnentag, O., Hufkens, K., Teshera-Sterne, C., Young, A. M., Friedl, M., Braswell, B. H., Milliman, T., O'Keefe, J., and Richardson, A. D.: Digital repeat photography for phenological research in forest ecosystems, Agr. Forest Meteorol., 152, 159177, 2012.

Specht, A.: Temperature effects on eucalypt shoot growth in the Brisbane region, PhD Thesis, University of Queensland, 1985.

Specht, R. L. and Brouwer, Y. M.: Seasonal Shoot Growth of Eucalyptus spp. In the Brisbane Area of Queensland (With Notes on Shoot Growth and Litter Fall in Other Areas of Australia), Aust. J. Bot., 23, 459-474, 1975.

Specht, R. L. and Specht, A.: Species richness of sclerophyll (heathy) plant communities in Australia - the influence of overstorey cover, Aust. J. Bot., 37, 337-350, 1989.

Stern, H. and Dehani, R. R.: The distribution of climate zones across Australia: identifying and explaining changes during the past century, 25th Conference on Climate Variability and Change, American Meteorological Society, Austin, TX, USA, 2013.

Stone, C., Chisholm, L., and Coops, N.: Spectral reflectance characteristics of eucalypt foliage damaged by insects, Aust. J. Bot., 49, 687-698, 2001.

Sugiharto, B., Miyata, K., Nakamoto, H., Sasakawa, H., and Sugiyama, T.: Regulation of expression of carbon-assimilating enzymes by nitrogen in maize leaf, Plant Physiol., 92, 963-969, 1990.

Taylor, J. R. and Loescher, H. L.: Automated quality control methods for sensor data: a novel observatory approach, Biogeosciences, 10, 4957-4971, doi:10.5194/bg-10-4957-2013, 2013.

Terashima, I. and Evans, J. R.: Effects of light and nitrogen nutrition on the organization of the photosynthetic apparatus in spinach, Plant Cell Physiol., 29, 143-155, 1988.

Tomlinson, K. W., Poorter, L., Sterck, F. J., Borghetti, F., Ward, D., de Bie, S., and van Langevelde, F.: Leaf adaptations of evergreen and deciduous trees of semi-arid and humid savannas on three continents, J. Ecol., 101, 430-440, 2013.

Toomey, M., Friedl, M. A., Frolking, S., Hufkens, K., Klosterman, S., Sonnentag, O., Baldocchi, D. D., Bernacchi, C. J., Biraud, S. C., Bohrer, G., Brzostek, E., Burns, S. P., Coursolle, C., Hollinger, D. Y., Margolis, H. A., McCaughey, H., Monson, R. K., Munger, J. W., Pallardy, S., Phillips, R. P., Torn, M. S.,
Wharton, S., Zeri, M., and Richardson, A. D.: Greenness indices from digital cameras predict the timing and seasonal dynamics of canopy-scale photosynthesis, Ecol. Appl., 25, 99-115, 2015.

Tucker, C. J.: Red and photographic infrared linear combinations for monitoring vegetation, Remote Sens. Environ., 8, 127-150, 1979.

Turton, S. M. and Stork, N. E.: Impacts of tropical cyclones on forests in the wet tropics of Australia, in: Living in a Dynamic Tropical Forest Landscape, edited by: Stork, N. E. and Turton, S. M., Wiley-Blackwell, Oxford, UK, 2008.

Van Dijk, A. I. J. M., Beck, H. E., Crosbie, R. S., De Jeu, R. A. M., Liu, Y. Y., Podger, G. M., Timbal, B., and Viney, N. R.: The Millennium Drought in southeast Australia (2001-2009): Natural and human causes and implications for water resources, ecosystems, economy, and society, Water Resour. Res., 49, 1040-1057, 2013.

van Gorsel, E., Berni, J. A. J., Briggs, P., Cabello-Leblic, A., Chasmer, L., Cleugh, H. A., Hacker, J., Hantson, S., Haverd, V., Hughes, D., Hopkinson, C., Keith, H., Kljun, N., Leuning, R., Yebra, M., and Zegelin, S.: Primary and secondary effects of climate variability on net ecosystem carbon exchange in an evergreen eucalyptus forest, Agr. Forest Meteorol., 182/183, 248256, 2013.

Venn, S. E. and Morgan, J. W.: Phytomass and phenology of three alpine snowpatch species across a natural snowmelt gradient, Aust. J. Bot., 55, 450-456, 2007.

Visser, M. D., Jongejans, E., van Breugel, M., Zuidema, P. A., Chen, Y. Y., Rahman Kassim, A., and de Kroon, H.: Strict mast fruiting for a tropical dipterocarp tree: A demographic cost-benefit analysis of delayed reproduction and seed predation, J. Ecol., 99, 1033-1044, 2011.

Walker, B. H. and Langridge, J. L.: Predicting savanna vegetation structure on the basis of plant available moisture (PAM) and plant available nutrients (PAN): A case study from Australia, J. Biogeogr., 24, 813-825, 1997.

Werner, P. A. and Franklin, D. C.: Resprouting and mortality of juvenile eucalypts in an Australian savanna: Impacts of fire season and annual sorghum, Aust. J. Bot., 58, 619-628, 2010.

Werner, P. A. and Prior, L. D.: Demography and growth of subadult savanna trees: Interactions of life history, size, fire season, and grassy understory, Ecol. Monogr., 83, 67-93, 2013.

Whitley, R. J., Macinnis-Ng, C. M. O., Hutley, L. B., Beringer, J., Zeppel, M., Williams, M., Taylor, D., and Eamus, D.: Is productivity of mesic savannas light limited or water limited? Results of a simulation study, Glob. Change Biol., 17, 3130-3149, 2011.

Williams, R. J., Myers, B. A., Muller, W. J., Duff, G. A., and Eamus, D.: Leaf phenology of woody species in a North Australian tropical savanna, Ecology, 78, 2542-2558, 1997.

Wingate, L., Ogeé, J., Cremonese, E., Filippa, G., Mizunuma, T., Migliavacca, M., Moisy, C., Wilkinson, M., Moureaux, C., Wohlfahrt, G., Hammerle, A., Hörtnagl, L., Gimeno, C., PorcarCastell, A., Galvagno, M., Nakaji, T., Morison, J., Kolle, O., Knohl, A., Kutsch, W., Kolari, P., Nikinmaa, E., Ibrom, A., Gielen, B., Eugster, W., Balzarolo, M., Papale, D., Klumpp, K. Köstner, B., Grünwald, T., Joffre, R., Ourcival, J. M., Hellstrom, M., Lindroth, A., George, C., Longdoz, B., Genty, B., Levula, J., Heinesch, B., Sprintsin, M., Yakir, D., Manise, T., Guyon, D., Ahrends, H., Plaza-Aguilar, A., Guan, J. H., and Grace, J.: Interpreting canopy development and physiology using a Euro- 
pean phenology camera network at flux sites, Biogeosciences, 12, 5995-6015, doi:10.5194/bg-12-5995-2015, 2015.

Woebbecke, D. M., Meyer, G. E., Von Bargen, K., and Mortensen, D. A.: Color indices for weed identification under various soil, residue, and lighting conditions, Trans. Am. Soc. Agr. Engin., 38, 259-269, 1995.

Wright, S. J. and van Schaik, C. P.: Light and the phenology of tropical trees, Am. Nat., 143, 192-199, 1994.

Wu, J., Albert, L. P., Lopes, A. P., Restrepo-Coupe, N., Hayek, M., Wiedemann, K. T., Guan, K., Strark., S. C., Christoffersen, B., Prohaska, N., Tavares, J. V., Marostica, S., Kobayashi, H., Ferreira, M. L., Campos, K. S., da Silva, R., Brando, P. M., Dye, D. G., Huxman, T. E., Huete, A., Nelson, B. W., and Saleska, S. R.: Leaf development and demography explain photosynthetic seasonality in Amazon evergreen forests, Science, 351, 972-976, 2016.
Zhu, W., Chen, G., Jiang, N., Liu, J., and Mou, M.: Estimating carbon flux phenology with satellite-derived land surface phenology and climate drivers for different biomes: A synthesis of AmeriFlux observations, PLoS ONE, 8, e84990, doi:10.1371/journal.pone.0084990, 2013. 